\title{
Embryonic Origin of the Islet1 and Pax6 Neurons of the Chicken Central Extended Amygdala Using Cell Migration Assays and Relation to Different Neuropeptide-Containing Cells
}

\author{
Alba Vicario Antonio Abellán Loreta Medina \\ Laboratory of Brain Development and Evolution, Department of Experimental Medicine, Faculty of Medicine, \\ University of Lleida, Institute of Biomedical Research of Lleida, Lleida, Spain
}

\begin{abstract}
Key Words
Anxiety - Avian telencephalon - Bed nucleus of the stria terminalis · Corticotropin-releasing factor - Enkephalin · Evolution · Fear responses - FoxP2 - Intercalated amygdalar cells · Motivation · Neurotensin · Nkx2.1 · Pallidal domains . Preoptic area Prethalamic eminence $\cdot$ Reward .

Somatostatin $\cdot$ Striatal domains
\end{abstract}

\section{Abstract}

In a recent study, we tentatively identified different subdivisions of the central extended amygdala (EAce) in chicken based on the expression of region-specific transcription factors (including Pax6 and Islet1) and several phenotypic markers during embryonic development. Such a proposal was partially based on the suggestion that, similarly to the subdivisions of the EAce of mammals, the Pax 6 and Islet 1 neurons of the comparable chicken subdivisions derive from the dorsal (Std) or ventral striatal embryonic domains (Stv), respectively. To investigate whether this is true, in the present study, we carried out cell migration assays from chicken Std or Stv combined with immunofluorescence for Pax6 or Islet1. Our results showed that the cells of the proposed chicken EAce truly originate in either Std (expressing Pax6)
\end{abstract}

or Stv (expressing Islet1). This includes lateral subdivisions previously compared to the intercalated amygdalar cells and the central amygdala of mammals, also rich in Std-derived Pax 6 cells and/or Stv-derived Islet 1 cells. In the medial region of the chicken EAce, the dorsal part of the lateral bed nucleus of the stria terminalis (BSTL) contains numerous cells expressing Nkx2.1 (mostly derived from the pallidal domain), but our migration assays showed that it also contains neuron subpopulations from the Stv (expressing Islet1) and Std (expressing Pax6), resembling the mouse BSTL. These findings, together with those previously published in different species of mammals, birds and reptiles, support the homology of the chicken EAce to that of other vertebrates, and reinforce the existence of several cell subcorridors inside the EAce. In addition, together with previously published data on neuropeptidergic cells, these results led us to propose the existence of at least seventeen neuron subtypes in the EAce in rodents and/or some birds (chicken and pigeon). The functional significance and the evolutionary origin of each subtype needs to be analyzed separately, and such studies are mandatory in order to understand the multifaceted modulation by the EAce of fear responses, ingestion, motivation and pain in different vertebrates.

(c) 2015 S. Karger AG, Basel

\section{KARGER 125\%}

(C) 2015 S. Karger AG, Basel

0006-8977/15/0853-0139\$39.50/0
Loreta Medina, $\mathrm{PhD}$

Departament de Medicina Experimental, Facultat de Medicina

Universitat de Lleida, Edifici Biomedicina I - IRB Lleida

Avda. Alcalde Rovira Roure 80, ES-25198 Lleida (Spain)

E-Mail loreta.medina @ mex.udl.cat 


\begin{tabular}{|c|c|c|c|}
\hline \multicolumn{4}{|c|}{ Abbreviations used in this paper } \\
\hline A & arcopallial amygdala & LGE & lateral ganglionic eminence (striatal division in \\
\hline ac & anterior commissure & & mammals) \\
\hline APH & parahippocampal area & LGEd & dorsal subdivision of the LGE \\
\hline $\operatorname{chp}$ & choroid plexus & LGEv & ventral subdivision of the LGE \\
\hline $\mathrm{BMC}$ & basal magnocellular complex & LSt & lateral striatum \\
\hline BST & bed nucleus of the stria terminalis & lv & lateral ventricle \\
\hline BSTL & lateral part of the BST & MGE & medial ganglionic eminence (pallidal division in \\
\hline BSTLd & dorsal part of the BSTL & & mammals) \\
\hline BSTLdi & intermediate division of BSTLd & MGEd & dorsal subdivision of MGE \\
\hline BSTLdl & lateral division of the BSTLd & MGEvc & ventrocaudal subdivision of the MGE (previously \\
\hline BSTLdm & medial division of the BSTLd & & included as part of the peduncular area) \\
\hline BSTM & medial part of the BST & MP & medial pallium \\
\hline BSTMp & preoptic division of the BSTM & MSt & medial striatum \\
\hline $\mathrm{CB}$ & calbindin & $\mathrm{N}$ & nidopallium \\
\hline $\mathrm{CeA}$ & central amygdalar nucleus & NT & neurotensin \\
\hline $\mathrm{CeC}$ & capsular part of the CeA & $\mathrm{Pa}$ & pallidal division \\
\hline CeL & lateral division of the $\mathrm{CeA}$ (mammal) & Pavc & ventrocaudal part of the $\mathrm{Pa}$ \\
\hline $\mathrm{CeM}$ & medial division of the $\mathrm{CeA}$ (mammal) & Pad & dorsal part of the $\mathrm{Pa}$ \\
\hline Ceov & oval central amygdalar nucleus (chicken) & pINP & peri-INP island field \\
\hline $\operatorname{chp}$ & choroid plexus & $\mathrm{PO}$ & preoptic area \\
\hline CRF & corticotropin-releasing factor & POC & commissural part of the PO \\
\hline DYN & dynorphin & Pov & perioval zone (chicken: part of the EAce) \\
\hline EAce & central extended amygdala & Se & septum \\
\hline ENK & enkephalin/enkephalinergic & SLEA & sublenticular extended amygdala \\
\hline EMT & prethalamic eminence & SOM & somatostatin \\
\hline GABA & $\gamma$-aminobutyric acid & SP & substance $\mathrm{P}$ \\
\hline Glut & glutamate & St & striatum or striatal embryonic domain (LGE like) \\
\hline GP & globus pallidus & $\mathrm{StC}$ & striatal capsule (part of the chicken ITC-like patches) \\
\hline Hy & hypothalalmus & Std & dorsal subdivision of St (LGEd-like) \\
\hline i1 & intermediate Std-derived cell stream & Stv & ventral division of the St (LGEv-like) \\
\hline & (or cell corridor), rich in Pax6 & $\mathrm{TH}$ & tyrosine hydroxylase \\
\hline INP & intrapeduncular nucleus & $\mathrm{Tu}$ & olfactory tubercle \\
\hline IPAC & interstitial nucleus of the posterior limb of the ac & $3 \mathrm{v}$ & third ventricle \\
\hline Isl1 & Islet1 & VP & ventral pallium \\
\hline ITC & intercalated cell masses & VTA & ventral tegmental area \\
\hline lfb & lateral forebrain bundle & & \\
\hline
\end{tabular}

\section{Introduction}

In mammals, the central extended amygdala (EAce) is a highly complex cell corridor of the basal telencephalon spanning from the central amygdalar nucleus (CeA), laterally, to the lateral bed nucleus of the stria terminalis (BSTL), medially [Alheid and Heimer, 1988; de Olmos et al., 2004]. In addition to the CeA and BSTL, it includes the intercalated cell masses (ITC), a medial part of the interstitial nucleus of the posterior limb of the anterior commissure and a dorsal (central) part of the sublenticular extended amygdala, among other structures [Alheid et al., 1999; de Olmos et al., 2004; Bupesh et al., 2011a]. The CeA, the ITC and the BSTL have been shown to be essen- tial for fear and anxiety responses [Phelps and LeDoux, 2005; Paré and Durvarci, 2012]. Moreover, the CeA and BSTL are also involved in emotional control or modulation of ingestion [Petrovich et al., 2009; Jennings et al., 2013a], pain [Fox and Sorenson, 1994; Kang et al., 1998] and reward/aversion [Jennings et al., 2013b]. Such multifaceted functions are controlled or modulated by different neuron subsets of the EAce and their projections. For example, anxiety-like responses are mediated by projection neurons containing corticotropin-releasing factor (CRF) mainly located in the lateral subnucleus of the CeA (CeL) and the BSTL, which are interconnected and show descending projections to hypothalamic and brainstem centers involved in neuroendocrine, autonomic and mo- 
tor somatic control [Walker and Davis, 2008; Walker et al., 2009; Davis et al., 2010].

The CeL, the medial subnucleus of the CeA (CeM) and the BSTL also include a different type of projection neurons, which contain the neuropeptide somatostatin (SOM) and show long descending projections to many of the brainstem centers associated to fear responses and nociception control, such as the periaqueductal gray [Gray and Magnuson, 1992; Penzo et al., 2014], the parabrachial nucleus [Moga and Gray, 1985; Moga et al., 1989; Panguluri et al., 2009] and the solitary tract nucleus [Higgins and Schwaber, 1983; Saha et al., 2002]. These neurons really include two distinct subpopulations, one co-expressing substance $\mathrm{P}$ (SP) located in CeM, and another one without SP located in CeL [Shimada et al., 1989], which appears to be more numerous [Real et al., 2009]. The SOM cells of the CeL with long descending projections have been related to fear learning and conditioning, and appear to regulate fear expression by a pathway independent of the CeM [Li et al., 2013; Penzo et al., 2014], which is the major output subnucleus of the CeA [Walker and Davis, 2008; Walker et al., 2009; Ciocchi et al., 2010; Davis et al., 2010]. These SOM cells of the CeL are the so-called CeL-on cells because they become active by a conditioned stimulus [ $\mathrm{Li}$ et al., 2013; Penzo et al., 2014]. In addition to their direct modulation of brainstem targets, activation of these SOM neurons produces inhibition of the so-called CeL-off cells (which are inhibited by a conditioned stimulus); since the CeL-off cells inhibit CeM output neurons, this leads to disinhibition of such neurons, thus releasing the fear response [Ciocchi et al., 2010; Haubensak et al., 2010; Li et al., 2013]. A part of the CeL-off cells contains the neuropeptide enkephalin (ENK), but none or extremely few express SOM or CRF [Haubensak et al., 2010; Li et al., 2013]. ENK neurons are located in the capsular $\mathrm{CeA}(\mathrm{CeC}), \mathrm{CeL}$ and BSTL, modulate the activity of other EAce neurons by way of intersubdivisional connections and may be involved in nociception and stress-induced analgesia [Kang et al., 1998; reviewed by Poulin et al., 2006, 2008]. These neurons are specifically activated following systemic administration of interleukin- $1 \beta$, a cytokine related to inflammatory pain hypersensitivity [Day et al., 1999]. However, some ENK neurons of the BSTL project to the ventral tegmental area (VTA) [Kudo et al., 2014] and may be involved in reward [Jennings et al., 2013b].

Recent evidence in the mouse suggests that the three different peptidergic neuron subtypes of the CeA mentioned above relate to different functional pathways, express different transcription factors during development and originate in distinct embryonic domains [Bupesh et

Islet1 and Pax6 Cells of Chicken Central

Extended Amygdala al., 2011a]. The majority of CeA neurons originate in either the dorsal lateral ganglionic eminence (LGEd) [Bupesh et al., 2011a] or the ventral lateral ganglionic eminence (LGEv) [Waclaw et al., 2010; Bupesh et al., 2011a]. LGEd-derived neurons express Pax6 during development [Flames et al., 2007], mostly populate the $\mathrm{CeC}$ and CeL, and appear to correspond to ENK neurons [Bupesh et al., 2011a]. LGEv-derived neurons express Islet1 during development [Waclaw et al., 2010; Bupesh et al., 2011a], mostly populate the $\mathrm{CeL}$ and $\mathrm{CeM}$, and appear to give rise to several peptidergic neurons, including those expressing CRF [Bupesh et al., 2011a]. On the other hand, SOM neurons of the CeA, distributed along the CeM and CeL, originate in the caudoventral part of the medial ganglionic eminence (MGEvc; i.e. the caudoventral or ventrocaudal pallidal domain, Pavc) and appear to express Nkx2.1/Lhx6 during development [García-López et al., 2008; Bupesh et al., 2011a]. The mouse LGEd and LGEv were also shown to produce subpopulations of Pax6- or Islet1-expressing neurons for the BSTL, which may correspond to at least part of the ENK and CRF neurons described in this nucleus [Bupesh et al., 2011a].

Knowledge on the evolutionary developmental origin of different neuron subtypes can contribute to a better understanding of the organization and adaptive value of different functional neuronal subsystems of the EAce. In a recent study, we tentatively identified several subdivisions of the EAce in the developing telencephalon of the chicken, based on the presence of cells expressing the transcription factors Pax6, Islet1 or Nkx2.1, and cells expressing the phenotypic markers ENK, CRF or SOM [Vicario et al., 2014]. We proposed that some of these different neuron subpopulations identified in chicken have an embryonic origin similar to those found in the EAce of mammals. Dorsal (Std) and ventral (Stv) subdomains of the striatum (St) are present in the embryonic striatal division of the chicken, which are comparable to mammalian LGEd and LGEv, respectively [Abellán and Medina, 2009; Vicario et al., 2014]. We proposed that the Pax6 cells of the chicken EAce originate in the Std, while the Isletl cells may originate in the Stv [Vicario et al., 2014], corresponding to the Pax6 and Islet 1 cells of the EAce of the mouse [Waclaw et al., 2010; Bupesh et al., 2011a]. Therefore, the aim of this study was to investigate whether this proposal is true using migration assays. Our data from migration assays demonstrate that many neurons of the chicken EAce, including subpopulations of the BSTL, derive from the Stv (expressing Islet1) and Std (expressing Pax6), resembling the EAce of the mouse [Waclaw et al., 2010; Bupesh et al., 2011a] and turtle [Moreno et al., 2010, 2012a, b]. 


\section{Material and Methods}

Chicken embryos (Gallus gallus domesticus; Leghorn) from embryonic days 8-9 (E8-E9 or HH34-HH35) until day 12 (E12 or $\mathrm{HH} 38)$ were used in the present study. All animals were treated according to the regulations and laws of the European Union (Directive 2010/63/EU) and the Spanish Government (Royal Decrees $1021 / 2005$ and 53/2013) for the care and handling of animals in research. The protocols used were approved by the committee for the handling and care of research animals of the University of Lleida. Chicken embryos were obtained from fertilized eggs bought in a specialized poultry farm, which were incubated in a forced-draft incubator until the desired embryonic stage. Upon extraction, they were staged according to Hamburger and Hamilton [1951] and their brains were processed for preparing organotypic cultures for in vitro migration assays. To better understand the results of the migration assays, some brains were processed for in situ hybridization, for immunohistochemistry or for immunofluorescence.

\section{Organotypic Cultures}

To study the embryonic origin of Pax6 and Islet 1 neurons, we performed organotypic culture of frontal slices of chicken forebrain at E8/E9 or mostly at E10, following a previously described procedure [Soria and Valdeolmillos, 2002] which was slightly modified according to Legaz [2006]. Upon extraction, embryos were placed in a standard ice-cold, oxygenated culture medium artificially resembling cerebrospinal fluid (containing $124 \mathrm{mM}$ $\mathrm{NaCl}, 5 \mathrm{mM} \mathrm{KCl}, 1.2 \mathrm{mM} \mathrm{KH}_{2} \mathrm{PO}_{4}, 1.3 \mathrm{mM} \mathrm{MgSO}_{4} \times 7 \mathrm{H}_{2} \mathrm{O}, 26 \mathrm{mM}$ $\mathrm{NaHCO}_{3}, 2.4 \mathrm{mM} \mathrm{CaCl}_{2} \times 2 \mathrm{H}_{2} \mathrm{O}$ and $10 \mathrm{~mm} \beta$-D-glucose [Soria and Valdeolmillos, 2002]), in which brains were dissected out. The brains were sectioned at $300 \mu \mathrm{m}$ in the frontal plane using a vibratome (Leica VT 1000S), and the slices were mounted onto porous culture plate inserts $(0.4-\mu \mathrm{m}$ pore diameter; $30-\mathrm{mm}$ insert diameter; Millicell-CM, Millipore, Molsheim, France) [Soria and Valdeolmillos, 2002] and placed in culture medium (DMEM F-12; Gibco, Grand Island, N.Y., USA) supplemented with 5\% fetal bovine serum, $0.1 \mathrm{mM}$ L-glutamine and 1\% of a 1:1 mix of penicillin/ streptomycin [Soria and Valdeolmillos, 2002; Legaz, 2006]. Slices were allowed to recover in a $\mathrm{CO}_{2}$ incubator $\left(5 \% \mathrm{CO}_{2} ; 37^{\circ} \mathrm{C}\right)$ for $1 \mathrm{~h}$ before application of the tracer dye. Subsequently, tungsten particles coated with the fluorescent dye CMFDA (Cell Tracker Green 5-chloromethylfluorescein diacetate; Invitrogen-Molecular Probes, Paisley, UK; excitation peak $490 \mathrm{~nm}$; emission peak 514 $\mathrm{nm}$ ) [Alifragis et al., 2002] were applied to the ventricular/subventricular zone of the following domains: (1) the Std or Stv (comparable to the LGEd and LGEv, respectively), which produce the vast majority of the Pax6 and Islet1 cells of the EAce in the mouse [Bupesh et al., 2011a] (CMFDA was applied at intermediate or caudal levels of these domains), and (2) the preoptic area (PO; especially, its commissural part), aiming to analyze the possible contribution of this area (also a source of Islet1 cells) to the chicken extended amygdala. Table 1 includes a selection of the best migration cases used for this study and shows details on embryo and brain slice numbers (experimental cases, including the hemisphere: 'R' for the right side of the slice and ' $L$ ' for the left side of the slice), section plane, location of the cell tracker application and immunofluorescence processing. Following application of the cell tracker, the slices were transferred to culture medium (Neurobasal; Gibco) supplemented with $5 \%$ fetal bovine serum, $0.1 \mathrm{mM} \mathrm{L}-$ glutamine, 1\% B27 supplement (Gibco) and $1 \%$ of a $1: 1$ mix of
Table 1. Experimental cases of migration assays

\begin{tabular}{|c|c|c|c|c|c|}
\hline Embryo & $\begin{array}{l}\text { Slice/ } \\
\text { case, } \\
\text { side }\end{array}$ & $\begin{array}{l}\text { Time of } \\
\text { incubation }\end{array}$ & Plane & $\begin{array}{l}\text { CFMDA } \\
\text { appli- } \\
\text { cation }\end{array}$ & $\begin{array}{l}\text { Immuno- } \\
\text { fluores- } \\
\text { cence }\end{array}$ \\
\hline c-Al-125 & 2 & $\mathrm{E} 8+24 \mathrm{~h}$ & Oblique & $\mathrm{PO}$ & Nkx2.1 \\
\hline c-Al-125 & $4, \mathrm{R}$ & $\mathrm{E} 8+24 \mathrm{~h}$ & Oblique & $\mathrm{PO}$ & Nkx2.1 \\
\hline c-Al-135 & $1, \mathrm{R}, \mathrm{L}$ & $\mathrm{E} 10+24 \mathrm{~h}$ & Frontal & Stv & Islet1 \\
\hline c-Al-135 & $2, \mathrm{R}$ & $\mathrm{E} 10+24 \mathrm{~h}$ & Frontal & Stv & Islet1 \\
\hline c-Al-135 & $3, \mathrm{R}$ & $\mathrm{E} 10+24 \mathrm{~h}$ & Frontal & $\mathrm{Pa}$ & Nkx2.1 \\
\hline c-Al-135 & $3, \mathrm{~L}$ & $\mathrm{E} 10+24 \mathrm{~h}$ & Frontal & $\mathrm{PO}$ & $\mathrm{Nkx} 2.1$ \\
\hline c-Al-135 & $4, \mathrm{R}$ & $\mathrm{E} 10+24 \mathrm{~h}$ & Frontal & Stv & Islet1 \\
\hline C-Al-136 & $1, \mathrm{R}$ & $\mathrm{E} 10+24 \mathrm{~h}$ & Frontal & Stv & Islet1 \\
\hline c-Al-144 & $1, \mathrm{R}$ & $\mathrm{E} 10+24 \mathrm{~h}$ & Frontal & Std & Pax6 \\
\hline C-Al-153 & $3, \mathrm{~L}$ & $\mathrm{E} 10+24 \mathrm{~h}$ & Frontal & Std & Pax6 \\
\hline c-Al-156 & $2, \mathrm{~L}$ & $\mathrm{E} 10+24 \mathrm{~h}$ & Frontal & Stv & Islet1 \\
\hline c-Al-159 & $1, \mathrm{~L}$ & $\mathrm{E} 10+24 \mathrm{~h}$ & Frontal & Stv & Islet1 \\
\hline c-Al-159 & $1, \mathrm{R}$ & $\mathrm{E} 10+24 \mathrm{~h}$ & Frontal & Stv & Islet1 \\
\hline c-Al-159 & $2, \mathrm{R}$ & $\mathrm{E} 10+24 \mathrm{~h}$ & Frontal & Std & Pax6 \\
\hline c-Al-159 & $3, \mathrm{~L}$ & $\mathrm{E} 10+24 \mathrm{~h}$ & Frontal & Std & Pax6 \\
\hline c-Al-159 & $4, \mathrm{R}$ & $\mathrm{E} 10+24 \mathrm{~h}$ & Frontal & Std & Pax6 \\
\hline c-Al-159 & $5, \mathrm{R}$ & $\mathrm{E} 10+24 \mathrm{~h}$ & Frontal & Stv & Islet1 \\
\hline c-Al-159 & $5, \mathrm{~L}$ & $\mathrm{E} 10+24 \mathrm{~h}$ & Frontal & Stv & Islet1 \\
\hline c-Al-187 & $2, \mathrm{R}, \mathrm{L}$ & $\mathrm{E} 10+24 \mathrm{~h}$ & Frontal & Std & Pax6 \\
\hline c-Al-191 & $1, \mathrm{~L}$ & $\mathrm{E} 10+24 \mathrm{~h}$ & Frontal & Std & Pax6 \\
\hline c-Al-192 & $1, \mathrm{~L}$ & $\mathrm{E} 10+24 \mathrm{~h}$ & Frontal & $\mathrm{Pa}$ & $\mathrm{Nkx} 2.1$ \\
\hline c-Al-194 & $2, \mathrm{R}, \mathrm{L}$ & $\mathrm{E} 10+24 \mathrm{~h}$ & Frontal & Std & Pax6 \\
\hline c-Al-194 & $3, \mathrm{R}$ & $\mathrm{E} 10+24 \mathrm{~h}$ & Frontal & $\mathrm{Pa}$ & Nkx2.1 \\
\hline c-Al-195 & $3, \mathrm{~L}$ & $\mathrm{E} 10+24 \mathrm{~h}$ & Frontal & Stv & Islet1 \\
\hline c-Al-197 & $1, \mathrm{R}$ & $\mathrm{E} 10+24 \mathrm{~h}$ & Frontal & Std & Pax6 \\
\hline c-Al-207 & $1, \mathrm{~L}$ & $\mathrm{E} 10+24 \mathrm{~h}$ & Oblique & Std & Pax6 \\
\hline c-Al-207 & $2, \mathrm{~L}$ & $\mathrm{E} 10+24 \mathrm{~h}$ & Oblique & Std & Pax6 \\
\hline c-Al-207 & $3, \mathrm{~L}$ & $\mathrm{E} 10+24 \mathrm{~h}$ & Oblique & $\mathrm{PO}$ & - \\
\hline c-Al-208 & $1, \mathrm{R}$ & $\mathrm{E} 10+24 \mathrm{~h}$ & Frontal & Std & Pax6 \\
\hline c-Al-208 & $2, \mathrm{~L}$ & $\mathrm{E} 10+24 \mathrm{~h}$ & Frontal & Std + Stv & Pax6 \\
\hline c-Al-209 & $1, \mathrm{R}$ & $\mathrm{E} 10+24 \mathrm{~h}$ & Oblique & Std & Pax6 \\
\hline c-Al-209 & $2, \mathrm{R}, \mathrm{L}$ & $\mathrm{E} 10+24 \mathrm{~h}$ & Oblique & Stv & Islet1 \\
\hline c-Al-211 & $1, \mathrm{R}$ & $\mathrm{E} 10+24 \mathrm{~h}$ & Frontal & $\mathrm{Stv}+\mathrm{Std}$ & Islet1 \\
\hline c-Al-211 & $3, \mathrm{~L}$ & $\mathrm{E} 10+24 \mathrm{~h}$ & Frontal & $\mathrm{PO}$ & - \\
\hline c-Al-211 & $2, \mathrm{R}, \mathrm{L}$ & $\mathrm{E} 10+24 \mathrm{~h}$ & Frontal & Stv + Std & Islet1 \\
\hline c-Al-212 & $1 \mathrm{R}, \mathrm{L}$ & $\mathrm{E} 10+24 \mathrm{~h}$ & Frontal & $\mathrm{PO}$ & - \\
\hline c-Al-212 & $2, \mathrm{R}$ & $\mathrm{E} 10+24 \mathrm{~h}$ & Frontal & Std & Pax6 \\
\hline c-Al-212 & $3, \mathrm{~L}$ & $\mathrm{E} 10+24 \mathrm{~h}$ & Frontal & Std & Pax6 \\
\hline
\end{tabular}

$\mathrm{R}=$ Right; $\mathrm{L}=$ left. Incubation: $38^{\circ} \mathrm{C}, 40 \%$ humidity.

penicillin/streptomycin [Soria and Valdeolmillos, 2002; Legaz, 2006], and incubated in a $\mathrm{CO}_{2}$ incubator $\left(5 \% ; 37^{\circ} \mathrm{C}\right)$ for $24 \mathrm{~h}$. After incubation, the slices were fixed with phosphate-buffered $4 \%$ paraformaldehyde $(\mathrm{pH} 7.4)$ for $8 \mathrm{~min}$, and then rinsed and stored in phosphate buffer $(0.1 \mathrm{M}, \mathrm{pH} 7.4)$ containing $0.1 \%$ sodium azide until microscopic observation. The labeling was analyzed and images were captured with a confocal scanning microscope (Olympus FV500 or Olympus FV1000). Selected slices were further processed for immunofluorescence, as described below. 
Table 2. Primary antibodies

\begin{tabular}{|c|c|c|c|c|c|}
\hline Antibody & Antigen recognized & Immunogen & $\begin{array}{l}\text { Manufacturer, species/ } \\
\text { mono- vs. polyclonal }\end{array}$ & $\begin{array}{l}\text { Catalog } \\
\text { No. }\end{array}$ & Dilution \\
\hline Anti-TTF-1 & Nkx2.1 (42 kDa) & $\begin{array}{l}\text { N-terminal residues } 110-122 \\
\text { of rat TTF-1 }\end{array}$ & $\begin{array}{l}\text { Biopat Immunotechnologies s.r.l./ } \\
\text { rabbit polyclonal }\end{array}$ & PA0100 & $1: 1,000$ \\
\hline Anti-Islet1 & $\begin{array}{l}\text { Islet } 1 / \text { Islet } 2 \\
(39 \mathrm{kDa})\end{array}$ & $\begin{array}{l}\text { C-terminal residues } 178-349 \\
\text { of rat Islet1 }\end{array}$ & $\begin{array}{l}\text { Developmental Hybridoma Bank/ } \\
\text { mouse monoclonal IgG } 2 b\end{array}$ & 39.4D5 & $1: 200$ \\
\hline Anti-Pax6 & Pax6 (46 kDa) & $\begin{array}{l}\text { Recombinant protein } \\
\text { containing amino acids } 1-223 \\
\text { of chick Pax6, made in E. coli }\end{array}$ & $\begin{array}{l}\text { Developmental Hybridoma Bank/ } \\
\text { mouse monoclonal IgG1 }\end{array}$ & Pax6 & $1: 200$ \\
\hline Anti-vimentin & Vimentin $(52 \mathrm{kDa})$ & $\begin{array}{l}\text { Developing chicken optic } \\
\text { tectum }\end{array}$ & $\begin{array}{l}\text { Developmental Hybridoma Bank/ } \\
\text { chicken monoclonal IgG1 }\end{array}$ & H5 & $1: 50$ \\
\hline
\end{tabular}

\section{In situ Hybridization}

Embryos were rapidly decapitated and their heads were fixed by immersion in phosphate-buffered $4 \%$ paraformaldehyde $(\mathrm{pH}$ 10.5, which is better to keep mRNA signals) [Basyuk et al., 2000], as previously described [Abellán and Medina, 2009]. After dissection and fixation, brains were embedded in $4 \%$ low-melt agarose and sectioned (70-90 $\mu \mathrm{m}$ thick) in a frontal plane using a vibratome (Leica VT 1000S). Brain sections were then processed for in situ hybridization and/or immunohistochemistry (next section).

Frontal brain sections were processed for in situ hybridization using digoxigenin-labeled riboprobes, following a procedure described previously [Medina et al., 2004; García-López et al., 2008; Abellán and Medina, 2009]. The riboprobes were synthesized from cDNAs of different genes, which were either purchased or obtained from other laboratories. The purchased clones were cDNA ESTs obtained from the BBSRC ChickEST Database [Boardman et al., 2002] or purchased from ARK-Genomics (Roslin Institute; Midlothian, UK) or Geneservice Limited (Cambridge, UK), and have the following GenBank accession numbers:

- cIslet1 (bp 6-458; GenBank accession No. NM_205414.1; BBSRC ChickEST Database; clone ChEST314A21);

- cPax6 (bp 849-1,964; GenBank accession No. NM_205066.1; plasmid obtained from J.L.R. Rubenstein's laboratory [Puelles et al., 2000]), and

- cLhx7/8 (bp 9-855; GenBank accession No. DQ082893.1; BBSRC ChickEST Database: clone ChEST766i11).

We synthesized the antisense digoxigenin-labeled riboprobes using the Roche Diagnostics (Mannheim, Germany) protocols for the genes mentioned above. Before hybridization, the sections were washed in PBS containing 0.1\% Tween-20 (1×), prehybridized in hybridization buffer for $2 \mathrm{~h}$ at $58^{\circ} \mathrm{C}$ and then hybridized in hybridization buffer containing the riboprobe overnight at $58^{\circ} \mathrm{C}$ $(0.5-1 \mu \mathrm{g} / \mathrm{ml}$, depending on the probe and brain size). The hybridization buffer contained $50 \%$ of deionized formamide, $1.3 \times$ standard saline citrate ( $\mathrm{pH} 5), 5 \mathrm{~mm}$ ethylenediaminetetraacetic acid ( $\mathrm{pH}$ 8.0; Sigma-Aldrich, Steinheim, Germany), $1 \mathrm{mg} / \mathrm{ml}$ of yeast tRNA (Sigma-Aldrich), 0.2\% Tween-20 and $100 \mu \mathrm{g} / \mathrm{ml}$ of heparin (Sigma-Aldrich), completed with water (free of RNAase and DNAase; Sigma-Aldrich). Following hybridization, the sections were first washed with a $1: 1 \mathrm{mix}$ of $1 \times$ MABT (1.2\% maleic acid, $0.8 \% \mathrm{NaOH}, 0.84 \% \mathrm{NaCl}$ and $0.1 \%$ Tween-20) and hybridization buffer at $58^{\circ} \mathrm{C}$ during $20 \mathrm{~min}$ and then abundantly with $1 \times$ MABT at room temperature (about $2 \mathrm{~h}$ ). Subsequently, the sections were blocked with a solution containing blocking reagent (Roche), $1 \times$ MABT and sheep serum (Sigma) for $4 \mathrm{~h}$ at room temperature, then incubated in an antibody against digoxigenin (alkaline-phosphatase-coupled anti-digoxigenin; diluted 1:3,500; Roche Diagnostics) overnight at $4^{\circ} \mathrm{C}$ followed by washing with $1 \times$ MABT and finally reacted with $\mathrm{BM}$ purple (Roche Diagnostics). Sections were then mounted on glycerol gelatin (Sigma).

\section{Immunohistochemistry and Immunofluorescence}

Selected series of embryonic brain sections were processed for immunohistochemistry to detect radial glial fibers using an antibody against vimentin (mouse anti-vimentin; obtained from Developmental Studies Hybridoma Bank; see details on the specificity below and in table 2 ). The primary antibody was diluted at 1:50 in PBS containing $0.3 \%$ Triton X-100, and the tissue was incubated for $2-3$ days at $4{ }^{\circ} \mathrm{C}$ under constant, gentle agitation. Following this incubation and standard washes in PBS-Triton, the sections were incubated in a secondary antiserum for $1 \mathrm{~h}$ at room temperature. The secondary antiserum used was a biotinylated goat anti-mouse antibody (diluted 1:200) purchased from Vector (Burlingame, Calif., USA). After washing, the sections were incubated in an avidinbiotin kit (ABC kit; Vector; $0.003 \%$ dilution) for $1 \mathrm{~h}$ at room temperature. Immunolabeling was performed with $0.05 \%$ diaminobenzidine (Sigma-Aldrich) in $0.05 \mathrm{M}$ Tris ( $\mathrm{pH} 7.6$ ), containing $0.03 \% \mathrm{H}_{2} \mathrm{O}_{2}$. Finally, the sections were rinsed, mounted and stored at $4^{\circ} \mathrm{C}$ until analysis.

Moreover, selected brain sections and selected slices from the migration experiments were processed for immunofluorescence to detect Pax6 (mouse anti-Pax6; Developmental Studies Hybridoma Bank, University of Iowa, Iowa City, Iowa, USA), Islet1 (mouse anti-Islet1; Developmental Studies Hybridoma Bank) or Nkx2.1 (rabbit anti-TTF-1; Biopat Immunotechnologies, Sant'Angelo a Cupolo, Italy; see table 2 and section below for details on the primary antibodies). The primary antibodies were diluted in PBS containing $0.3 \%$ Triton $\mathrm{X}-100$, and the tissue was incubated for $2-3$ days at $4{ }^{\circ} \mathrm{C}$ under constant, gentle agitation. To 
block nonspecific binding of the secondary antisera, $10 \%$ normal goat serum (Sigma) was added to the solution containing the Pax6, Islet1 and Nkx2.1 primary antibodies. After this incubation and standard washes in PBS-Triton, the sections were incubated in a secondary antiserum for $2 \mathrm{~h}$ at room temperature (although some of them were incubated overnight at $4^{\circ} \mathrm{C}$ under agitation). We used the following secondary antisera: donkey anti-mouse (for Pax6 and Islet1) and goat anti-rabbit (for Nkx2.1), all conjugated to Alexa 568 (Molecular Probes) and diluted 1:500. After incubation, the sections were rinsed and stored (at $4^{\circ} \mathrm{C}$ in the darkness) until analysis with a confocal microscope. To check the specificity of our secondary antisera, some sections were processed omitting the primary antibody, after which no labeling was observed.

\section{Antibody Characterization}

The mouse anti-vimentin (H5 antibody) was developed by Herman et al. [1993] as a radial glial cell marker and was obtained from the Developmental Studies Hybridoma Bank (created by the NICHD of the NIH and maintained at the Department of Biology of the University of Iowa). This antibody recognizes a band of about $52-\mathrm{kDa}$ on Western blots of chicken midbrain, which corresponds to the molecular weight of vimentin according to the manufacturer's data sheet [Herman et al., 1993].

The mouse anti-Islet1 antibody was obtained from the Developmental Studies Hybridoma Bank (catalog No. 39.4D5). It was raised against the C-terminal residues 178-349 of rat Islet1/Islet2, produces a comparable staining pattern in rat and chicken brain, and recognizes both Islet1 and Islet2 [Thor et al., 1991; VarelaEchavarría et al., 1996]. In the chicken brain, staining with this antiserum co-localizes with the mRNA distribution of Islet 1 protein by in situ hybridization histochemistry [Varela-Echavarría et al., 1996; Abellán and Medina, 2009; Vicario et al., 2014]. Moreover, the staining pattern obtained with this antibody in the developing chicken forebrain is highly similar to that obtained in mice and turtles using either the same [Bupesh et al., 2011a] or a different antibody [Moreno et al., 2010].

The mouse anti-Pax6 antibody was developed by Kawakami et al. [1997] and obtained from the Developmental Studies Hybridoma Bank. It was raised against a recombinant protein containing amino acids 1-223 of chick Pax6, made in Escherichia coli [Kawakami et al., 1997]. On Western blot of chicken retina, it recognizes two major bands of 46 and $48 \mathrm{kDa}$ and two minor bands of 38 and $40 \mathrm{kDa}$ [Kawakami et al., 1997], which possibly correspond to different isoforms. On Western blots of turtle and rat brain, it recog- nizes a single band of about $46 \mathrm{kDa}$, which corresponds to the molecular weight of the Pax6 protein [Moreno et al., 2010]. The staining pattern obtained with this antibody in the developing chicken forebrain is identical to that obtained with in situ hybridization [Abellán and Medina, 2009; Vicario et al., 2014], and it is similar to that obtained with the same antibody in the brain of different species, including mice and turtles [Kawakami et al., 1997; Moreno et al., 2010].

The rabbit anti-Nkx2.1 (anti-TTF-1) was raised against the $\mathrm{N}$ terminal residues 110-122 of rat Nkx2.1 (Biopat Immunotechnologies; catalog No. PA0100). On Western blots of turtle and rat brain samples, it recognizes a single band of about $42 \mathrm{kDa}$, which corresponds to the molecular weight of the protein [Moreno et al., 2010]. The staining pattern obtained with this antibody in the developing chicken forebrain is identical to that obtained with in situ hybridization [Abellán and Medina, 2009; Vicario et al., 2014]. Moreover, the staining pattern obtained with this antibody in the developing chicken forebrain is highly similar to that obtained in mouse and turtle forebrain [Moreno et al., 2010; Bupesh et al., 2011a].

\section{Digital Photographs and Figures}

Digital photographs from hybridized and diaminobenzidineimmunostained sections were taken with a Leica microscope (DMR HC) equipped with a Zeiss AxioVision digital camera, and images from migration assays and sections or slices processed for immunofluorescence were obtained with a confocal microscope (Olympus FV500 or FV1000). A few sections of Nkx2.1 immunofluorescence (seen in fig. 9 of this paper) were analyzed and photographed using an Olympus BX51 fluorescence microscope and a digital camera (Olympus DP70) at Dr. Agustín González's laboratory (Complutense University of Madrid, Spain). Selected digital images were adjusted for brightness/contrast using Adobe PhotoShop, and figures were mounted and labeled using FreeHand.

\section{Identification of Cell Masses and Nomenclature}

For the identification of forebrain cell masses, we primarily followed the proposal of the Avian Brain Nomenclature Forum [Reiner et al., 2004] and the chick brain atlas [Puelles et al., 2007]; for the developing chicken brain, we followed the approach reported by Puelles et al. [2000] as well as our own publications on the subject [Abellán and Medina, 2009; Abellán et al., 2010], particularly a recent publication in which we identified the subdivisions of the EAce in developing chicken [Vicario et al., 2014].
Fig. 1. $\mathbf{a}, \mathbf{b}, \mathbf{d}-\mathbf{g}^{\prime}$ Digital images from one representative organotypic culture of a telencephalic frontal slice of a chicken embryo (cAl-135a; E10), at an intermediate telencephalic level, in which the fluorescent cell tracker CMFDA (CFDA, green) was centered in the Stv. The slice was immunolabeled to detect Islet1, which helped to confirm the location of the cell tracker application and migrated cells (d, f, $\mathbf{g}$; shown in red). c To distinguish between cells migrating radially or tangentially, we show a similar frontal section immunostained for vimentin (using H5 antibody), which labels radial glial fibers. Stv-derived cells appeared to primarily migrate radially to the
St and the pINP, as inferred from their radial dispersion with respect to their origin and the radial orientation of the leading process in many of them. In addition, some cell subpopulations were observed to migrate tangentially to more ventral parts of the subpallium (arrow in b), reaching pallidal regions. Some of these invaded the rostral pole of the Ceov $(\mathbf{d})$. Like those in the St, part of the Stv-derived cells of the pINP and Ceov were double labeled for Islet1 (arrows in $\mathbf{e}-\mathbf{g}$; detail in $\mathbf{e}^{\prime}-\mathbf{g}^{\prime}$ taken from the squared area in $\mathbf{e}-\mathbf{g}$ ). Scale bar in $\mathbf{e}$ also applies to $\mathbf{f}, \mathbf{g}$, and bar in $\mathbf{f}^{\prime}$ also applies to $\mathbf{e}^{\prime}, \mathbf{g}^{\prime}$. See online version for colors and list for abbreviations.

(For figure see next page.)
144

Brain Behav Evol 2015;85:139-169 DOI: $10.1159 / 000381004$ 


\section{Color illustration online only!}
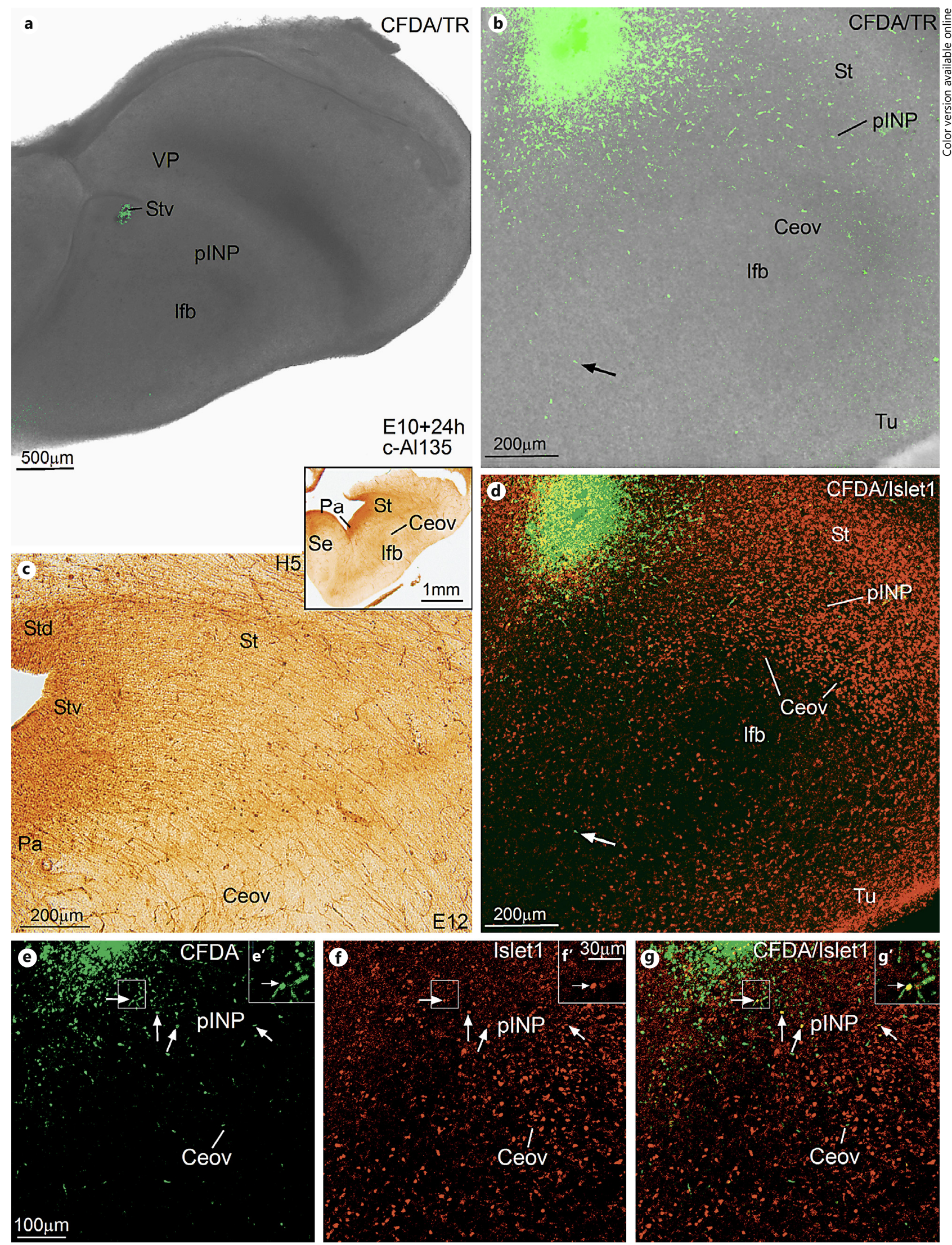

Islet1 and Pax6 Cells of Chicken Central

Brain Behav Evol 2015;85:139-169 DOI: $10.1159 / 000381004$ 


\section{Results}

The Chicken Stv Produces Islet1-Expressing Cells for the Oval CeA, the Peri-Intrapeduncular Island Field, the Rostral Subpallial Extended Amygdala and the Dorsal BSTL

To know whether Islet1 neurons of the proposed subdivisions of the chicken EAce originate in the Stv, we performed cell migration assays at E10 (an age when these subdivisions are already visible). Similar to the mouse LGEv, the chicken Stv is characterized by expression of Islet 1 in the subventricular and mantle zone during development [Abellán and Medina, 2009; Vicario et al., 2014]. Therefore, we used Islet 1 as the main genetic marker to be sure of the location of the cell tracker (to distinguish Stv from Std and pallidum, we also performed comparisons with Pax6, Nkx2.1 and other genetic markers of the chicken embryonic brain collection available in our laboratory from previous studies, such as Abellán and Medina [2009] and Vicario et al. [2014]). Following CMFDA application in the Stv, we consistently observed numerous labeled cells migrating to the striatal mantle (about 7-13 cells per $100 \times 100 \mu \mathrm{m}^{2}$, measured in single central confocal images of 9- $\mu \mathrm{m}$ step z-projection series in the medial striatal (MSt) mantle of four distinct E10 cultures - at intermediate (fig. 1a, b, d, 2a, c, d) and caudal telencephalic levels (fig. 3a, d, 4a); for checking the location of the cell tracker, please compare with Islet1 in figure $1 \mathrm{~d}, 2 \mathrm{~b}, \mathrm{c}, 3 \mathrm{~b})$. The migrated cells overlap there with Islet 1 cells that typically populate this region (mRNA: fig. 2b; immunofluorescence: fig. 1d, 2c, 4a; also compare fig. $2 \mathrm{~d}$ with $2 \mathrm{e}, \mathrm{f})$. Comparison with radial glial fiber disposition (H5 labeling in fig. 1c, 3c) showed that the Stvderived labeled cells primarily followed a radial migration from the progenitor zone to the striatal mantle, as inferred from their radial dispersion with respect to their ventricular origin and the radial orientation of the leading process in many of them (compare fig. $1 \mathrm{~b}$ with $1 \mathrm{c}$ at intermediate telencephalic levels or fig. $3 \mathrm{c}$ with $3 \mathrm{~d}$ at caudal telencephalic levels). Radially oriented migratory cells also reached the peri-intrapeduncular island field (pINP;

Fig. 2. a, c-i' Digital images from one representative organotypic culture of a telencephalic frontal slice of a chicken embryo (c-Al159a; E10), at an intermediate telencephalic level, in which the fluorescent cell tracker CMFDA (CFDA, green) was centered in the Stv. The slice was immunolabeled to detect Islet1, which helped to confirm the location of the cell tracker application and migrated cells (c, e, f, h, i; shown in red). Stv-derived cells are observed in the St, pINP and the rostral pole of Ceov (c-f). At medial levels, fig. $1 \mathrm{~b}, 2 \mathrm{c}, \mathrm{d}, 3 \mathrm{~d}, \mathrm{e}, 4 \mathrm{a}$ ), which is one of the proposed subdivisions of the chicken EAce [Vicario et al., 2014]. Scattered Stv-derived cells were also observed in the globus pallidus (GP; fig. 2c; in chicken, the GP is ectopically located within the striatal radial division [Puelles et al., 2007; Abellán and Medina, 2009; Medina et al., 2014]).

In addition, we also consistently observed subpopulations of Stv-derived cells that migrated tangentially to either the pallium (fig. $2 c, g$, i) or more ventral parts of the subpallium (arrow in fig. 1b, d; see also fig. $2 \mathrm{~g}$, i). Among the latter, we observed cells that invaded ventral parts of the MSt but also several subdivisions of the EAce, such as the dorsal BSTL (BSTLd), the rostral division of the subpallial amygdalar area (SpAr; fig. 2g, i), and the oval CeA (Ceov; fig. 3d, 4c, g). More specifically, at medial levels, we identified a cell corridor with tangentially oriented neuroblasts at a subventricular position, reaching the ventral part of the MSt but also the BSTLd (fig. 2g, 4f, h). In particular, cells migrating through the subventricular cell corridor reached the medial subdivision of the BSTLd (BSTLdm), overlapping there with Islet 1 immunofluorescent cells (fig. 2g, i, 4f). More laterally, we also identified a second cell corridor at an intermediate position within the lateral telencephalic wall (fig. $4 \mathrm{f}, \mathrm{h}$ ); cells migrating through this second corridor reached the SpAr at intermediate telencephalic levels (fig. 2g, i), or the intermediate (BSTLdi) and lateral BSTLd (BSTLdl) at intermediate (fig. $2 \mathrm{~g}, \mathrm{i}$ ) and/or caudal telencephalic levels (fig. $4 \mathrm{a}, \mathrm{f}, \mathrm{h}$, j). At caudal levels, cells migrating through this second corridor also reached the Ceov (fig. 3d, 4c, g). The migrated labeled cells overlapped with Islet1-immunofluorescent cells present in some of these locations, especially in the SpAr, BSTLdl and Ceov. Finally, following CMFDA application in the Stv, we also found tangentially migrating cells near the subpallial pial surface, which were located within the olfactory tubercle (Tu; fig. 1b, 2c, 3d).

Analysis of cell tracker/Islet1 colocalization at higher magnification showed cases of Stv-derived labeled cells that were immunofluorescent for Islet1, which were located within the St and pINP (arrows in fig. 1e-g, 2d-f, $3 \mathrm{e}-\mathrm{g}$; detail in $1 \mathrm{e}^{\prime}-\mathrm{g}^{\prime}, 3 \mathrm{e}^{\prime}-\mathrm{g}^{\prime}$ ), but also in the Tu, the SpAr

Stv-derived cells reached ventral parts of the MSt, SpAr and BSTLd by tangential migration $(\mathbf{g}-\mathbf{i})$. Part of the Stv-derived cells in all of these subdivisions were double labeled for Islet1 (arrows in $\mathbf{d}-\mathbf{i}$; detail in $\mathbf{d}^{\prime}-\mathbf{i}^{\prime}$ taken from the squared areas in $\left.\mathbf{d}-\mathbf{i}\right)$. b For comparison, a similar frontal section hybridized for Islet1 is shown where the St and several subdivisions of the EAce are evident. Scale bar in $\mathbf{d}$ also applies to $\mathbf{e}-\mathbf{i}$, and scale bar in $\mathbf{d}^{\prime}$ also applies to $\mathbf{e}^{\prime}-\mathbf{i}^{\prime}$. See online version for colors and list for abbreviations.

(For figure see next page.)
146

Brain Behav Evol 2015;85:139-169 DOI: $10.1159 / 000381004$ 


\section{Color illustration online only!}
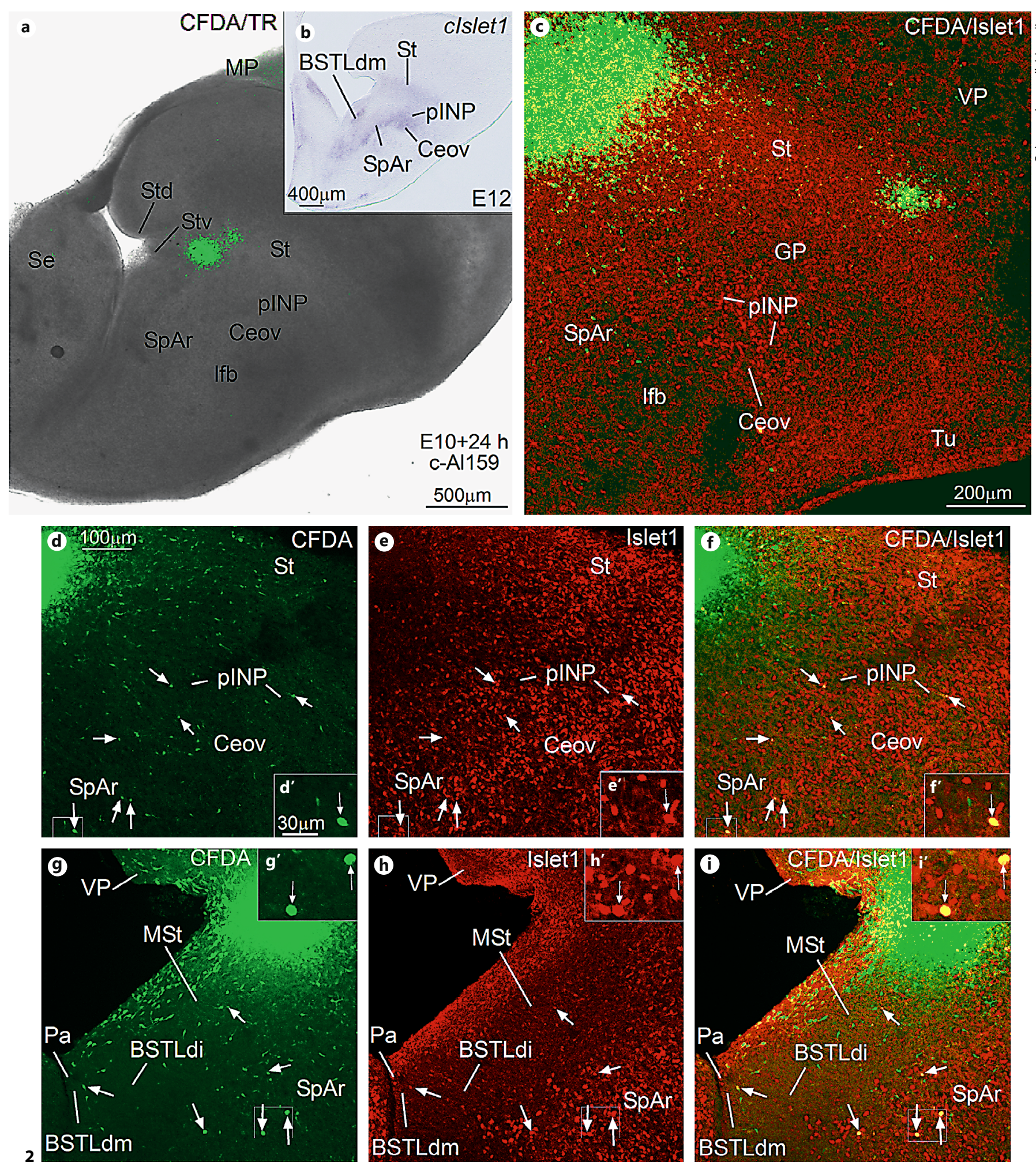

Islet1 and Pax6 Cells of Chicken Central

Brain Behav Evol 2015;85:139-169

DOI: $10.1159 / 000381004$ 
(arrows in fig. $2 \mathrm{~d}-\mathrm{i}$; detail in $\mathrm{d}^{\prime}-\mathrm{f}^{\prime}, \mathrm{g}^{\prime}-\mathrm{i}^{\prime}$ ), the BSTLd (arrows in fig. $2 \mathrm{~g}-\mathrm{i}, 4 \mathrm{~h}-\mathrm{j}$; detail in $4 \mathrm{~h}^{\prime}-\mathrm{j}^{\prime}$ ) and the Ceov (arrows in fig. $4 c, d$, g; detail in $\left.4 c^{\prime}, d^{\prime}, g^{\prime}\right)$.

The Chicken Std Produces Pax6-Expressing Cells for the $S t C$, the CeC, the PINP and the BSTLd

To know whether the Pax6 neurons of the proposed subdivisions of the chicken EAce originate in the Std, we carried out cell migration assays at E10 (when these subdivisions are already visible). As in the mouse LGEd, during development, the chicken Std is characterized by expression of Pax6 in the ventricular/subventricular zones and mantle [Abellán and Medina, 2009; Vicario et al., 2014] and expression of FoxP2 in the mantle [GarcíaCalero and Scharff, 2013; García-Calero et al., 2013]. Therefore, we used Pax6 and FoxP2 as the main genetic markers to be sure of the location of the cell tracker (to distinguish Std from Stv and pallium, we also performed comparisons with Islet1, Tbr1, Lhx9, vGLUT2 and other genetic markers of chicken embryonic brain available from our laboratory from previous studies, such as Abellán and Medina [2009], Abellán et al. [2009] and Vicario et al. [2014]). Following CMFDA application to the Std [for comparison, see Pax6 (fig. 5c, e, 6c, 7a, c) and FoxP2 (fig. $5 c^{\prime}$ )], we consistently observed many radially oriented migratory neuroblasts through the striatal capsule (StC) and adjacent parts of the developing Std (about 7-9 per $100 \times 100 \mu \mathrm{m}^{2}$, measured in single central confocal images of $9-\mu \mathrm{m}$ step $\mathrm{z}$-projection series in the MSt mantle of three distinct E10 cultures - at intermediate (fig. 5a, b, $6 \mathrm{~h}, \mathrm{i}$ ) and caudal telencephalic levels (fig. $6 \mathrm{a}-\mathrm{c}, 7 \mathrm{~b}, \mathrm{c}$ ). The migrated cells overlap with the Pax6 cells that characterize these striatal regions (mRNA: fig. $5 c, 7 \mathrm{a}$ and red immunofluorescence: fig. 5e, f, 6c, k, 7c). The radial orientation of these cells became evident by comparison with radial glial fibers (fig. $6 \mathrm{~g}$ ) and the radial orientation of the leading process in many of these cells (fig. $6 \mathrm{~d}$ ). Some of the Std-derived labeled cells also reached the developing $\mathrm{Tu}$ at a subpial position.

Fig. 3. a, $\mathbf{d}-\mathbf{g}$ Digital images from one representative organotypic culture of a telencephalic frontal slice of a chicken embryo (c-Al135b; E10), at a caudal telencephalic level, in which the fluorescent cell tracker CMFDA (CFDA, green) was centered in the Stv. The slice was immunolabeled to detect Islet1, which helped to confirm the location of the cell tracker application and migrated cells $(\mathbf{f}, \mathbf{g}$; shown in red). Many Stv-derived cells are observed in the St, pINP and Ceov. b, c For comparison, frontal sections at a similar age and level are shown, hybridized for Islet1 (clearly showing Ceov) or immunostained for vimentin (H5, showing the radial glial fibers).
In addition, we also consistently observed subpopulations of Std-derived cells that migrated tangentially to either the pallium (fig. $5 \mathrm{~d}$, $\mathrm{f}$; these cells in the pallium resembled morphologically migratory neuroblasts, with a leading process tangentially oriented towards the pallium) or more ventral parts of the subpallium, including ventral parts of the MSt and several subdivisions of the EAce (fig. 5b, g, 7c). Among the latter, from lateral to medial, we consistently observed labeled cells invading the CeC (fig. 6b, c, 7d, f), pINP (fig. 6b, c, i, k, 7d, f, g, i) and BSTLd (fig. 5g, i, 7c). In contrast, we only occasionally observed Std-derived labeled cells in the Ceov (fig. 6b, c, $7 \mathrm{~d}, \mathrm{f})$. In the $\mathrm{CeC}$ and pINP, Std-derived labeled cells overlapped with Pax6 immunofluorescent cells (fig. 6c, k, $7 \mathrm{f})$. In the BSTLd, only part of the migrating cells overlapped with Pax6 cells, and such overlapping mainly occurred in the BSTLdi and BSTLdl, where the Std-derived/ Pax6-expressing intermediate cell corridor appeared to arrive (il in fig. 5i, 7c).

Analysis of cell tracker/Pax6 colocalization at higher magnification showed cases of Std-derived labeled cells that were immunofluorescent for Pax6, located within the StC (arrow in fig. 5d-f; detail in $\mathrm{d}^{\prime}-\mathrm{f}^{\prime}$ ), MSt (arrows in fig. 5g-i), BSTLd (arrow in fig. 5g-i; detail in $\mathrm{g}^{\prime}-\mathrm{i}^{\prime}$ ), pINP (arrows in fig. 6b, c, i, j; detail in $6 \mathrm{~d}-\mathrm{f}, \mathrm{i}^{\prime}-\mathrm{k}^{\prime}$; $7 \mathrm{~d}-\mathrm{f}$, g-i; detail in $\mathrm{g}^{\prime}-\mathrm{i}^{\prime}$ ) and $\mathrm{CeC}$ (arrows in fig. $7 \mathrm{~d}$, e; detail in $\mathrm{d}^{\prime}, \mathrm{e}^{\prime}$ ).

\section{PO Is Also a Source of Islet1-Expressing Cells, but Only Few Reach the EAce}

Previous studies showed that the embryonic PO (characterized by ventricular zone and mantle expression of Nkx2.1, Shh and Lhx7/8) is another source of Islet1-expressing cells for the telencephalon [Abellán and Medina, 2009; Vicario et al., 2014]. To know whether any of the Islet 1 neurons of the proposed subdivisions of the chicken EAce originate in the embryonic PO, we carried out cell migration assays at E10 (an age when these subdivisions are already visible) and earlier (E7-E8, when most of the cells of this domain generate). To check the location

At this section level, it is possible to see that the Ceov is displaced ventrally from the striatal radial division (cf. a-c) and located inside the Pa (similarly to the BSTLd). Therefore, Stv-derived cells appear to arrive there through tangential migration. In contrast, cells reaching the St and pINP appear to follow a radial migration. Part of the Stv-derived cells were double labeled for Islet1 (see also cases shown in fig. 1,2), and an example is shown here in the pINP (arrow in $\mathbf{e - g}$; detail in $\mathbf{e}^{\prime}-\mathbf{g}^{\prime}$ taken from the squared areas in $\mathbf{e - g}$ ). Scale bar in e also applies to $\mathbf{f}, \mathbf{g}$, and in $\mathbf{e}^{\prime}$ also to $\mathbf{f}^{\prime}, \mathbf{g}^{\prime}$. See online version for colors and list for abbreviations.

(For figure see next page.)
148

Brain Behav Evol 2015;85:139-169 DOI: $10.1159 / 000381004$ 


\section{Color illustration online only!}

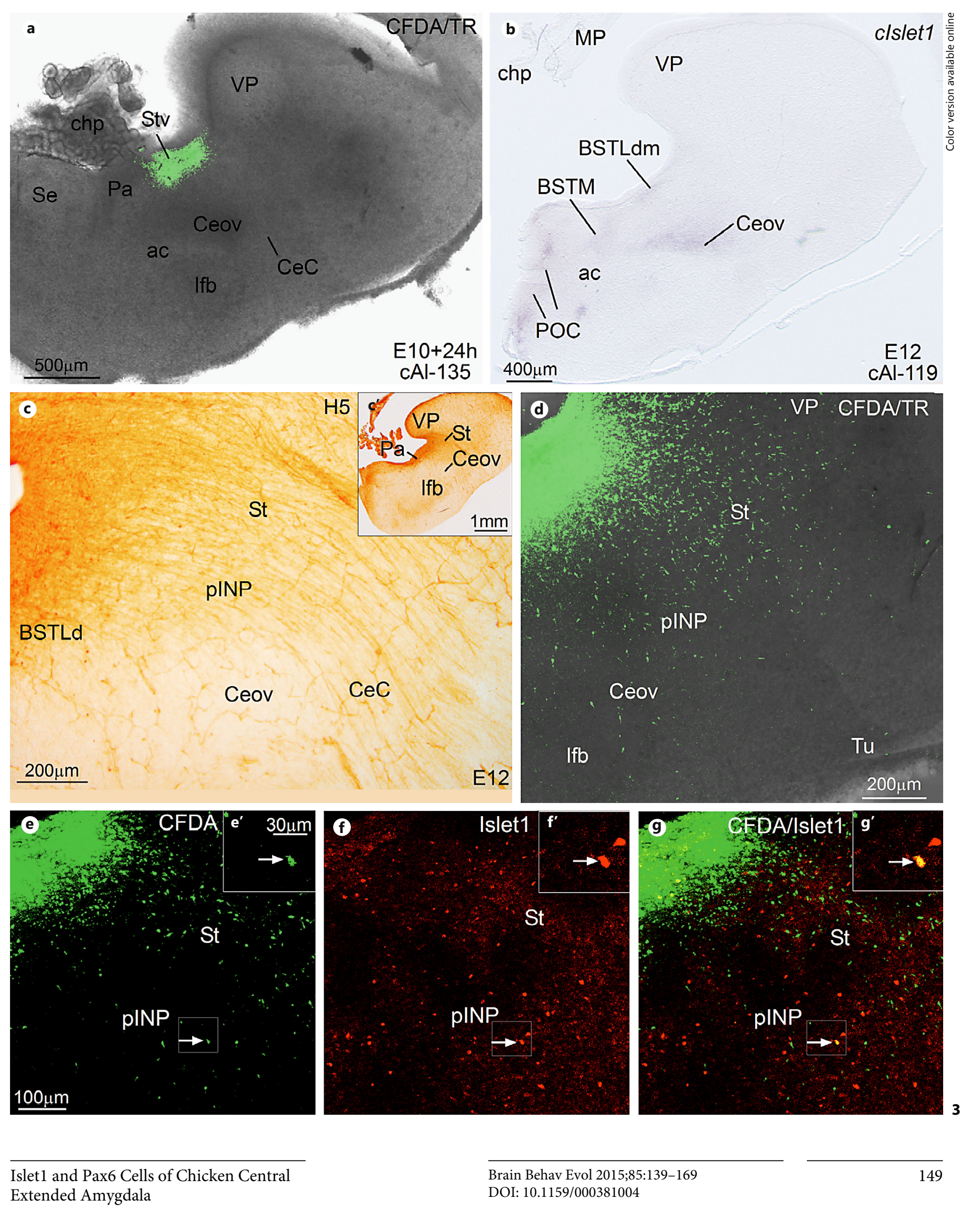


of the cell tracker, we compared our results with previous data on the expression of Nkx2.1, Shh, Lhx7/8 and Islet1 available in our laboratory [Abellán and Medina, 2009; Vicario et al., 2014]. Following CMFDA application in the PO at E10, we consistently observed labeled cells in the PO, but only extremely few migrated long distances from the center of cell tracker application and reached the BSTLd (fig. 8h; for comparison, in fig. 8g we show $\operatorname{Lhx} 7 / 8$, which defines the commissural PO, where we placed the CMFDA cell tracker). For that reason, we carried out cell migration assays at E7-E8. After CMFDA application in the $\mathrm{PO}$ at E7-E8, we consistently observed labeled cells in the whole radial dimension of the $\mathrm{PO}$, and also labeled cells with a morphology of tangentially oriented migratory neuroblasts invading other parts of the subpallium. Some of the latter entered the primordia of the medial extended amygdala, mainly the medial BST (BSTM; fig. 8a, c, d; detail in $\left.\mathrm{e}^{\prime}, \mathrm{e}^{\prime \prime \prime}\right)$ and the caudal aspect of BSTLd $\left(8 \mathrm{c}\right.$; detail in $\left.\mathrm{f}^{\prime}, \mathrm{f}^{\prime \prime \prime}\right)$. For comparison, we show Islet 1 in figure $8 \mathrm{~b}$ at a similar section level to that of the selected migration case shown in figure $8 \mathrm{a}$ (Islet 1 is expressed in the PO, BSTM, BSTLd and Ceov). Double labeling showed cases of PO-derived labeled cells in the BSTM (arrows in fig. $8 \mathrm{e}^{\prime}-\mathrm{e}^{\prime \prime \prime}$ ) and BSTLd (arrows in fig. $8 \mathrm{f}^{\prime}-\mathrm{f}^{\prime \prime \prime}$ ) expressing the transcription factor $\mathrm{Nkx} 2.1$. In contrast, we observed no labeled cells in the Ceov. The scarcity of $\mathrm{PO}$-derived labeled cells in the Ceov in our migration assays was in consonance with the poor signal in this nucleus for Nkx2.1 mRNA [Vicario et al., 2014] and for Lhx7/8 mRNA (fig. 8g), and with the scarcity of cells containing $\mathrm{Nkx} 2.1$ protein (fig. 9a, b; detail in $9 \mathrm{c}$; for comparison, the GP is seen in the same section and is rich in Nkx2.1-expressing cells). Since Nkx2.1 is expressed in cells derived from both the pallidal division $(\mathrm{Pa})$ and the $\mathrm{PO}$, this means that the Ceov is poor in such cell type. This suggests that the vast majority of the Islet 1 cells of the Ceov might derive from the Stv. On the other hand, the BSTLd contained abundant cells expressing Nkx2.1 (fig. 9b, d), which was in agreement with the putative pallidal origin of the majority of its cells (the majority of the Nkx2.1 cells were found in BSTLdm and BSTLdl). Nevertheless, our experiments showed that part of the Nkx2.1 cells found in the BSTLd (at least at very caudal levels) derive from the PO. Regarding the pINP, it also contained cells expressing Nkx2.1, although these were less abundant than those in pallidal areas (such as the GP or the BSTLd) or the PO (fig. 9b, d-f). Since cells of PO origin reaching the pINP were absent in our experiments, it is expected that the vast majority of the $\mathrm{Nkx} 2.1$ cells found in the pINP derive from the pallidum.

\section{Discussion}

In a recent study, we tentatively identified different subdivisions of the EAce in chicken based on the expression of three region-specific transcription factors (Pax6, Islet 1 and $\mathrm{Nkx} 2.1$ ) and four phenotypic markers (including ENK, CRF and SOM) during embryonic development [Vicario et al., 2014]. Such proposal was partially based on the suggestion that, similarly to the central amygdala and other parts of the EAce of mammals [Waclaw et al., 2010; Bupesh et al., 2011a], Pax6 and Islet 1 neurons of the comparable chicken subdivisions derive from the Std (LGEd-like) or Stv (LGEv-like) embryonic domains, respectively. To investigate the embryonic origin of these neurons in chicken, in the present study, we carried out cell migration assays from the Std or Stv combined with immunofluorescence for Pax6 or Islet1. Our results showed that, indeed, numerous cells of the proposed chicken EAce originate in either the Std or Stv, part of which express Pax6 (from the Std) or Islet1 (from the Stv; fig. 10a). This includes lateral subdivisions previously compared to the intercalated amygdalar cells (including the chicken StC) and the central amygdala (the chicken pINP, CeC and Ceov) [Vicario et al., 2014; present results], which in mammals are also rich in LGEd-derived Pax6 and FoxP2 cells and/or LGEv-derived Islet1 cells [Kaoru et al., 2010; Waclaw et al., 2010; Bupesh et al., 2011a]. In general, only minor neuron subpopulations of pallido-preoptic origin (expressing $\mathrm{Nkx} 2.1$ ) are found in these lateral subdivisions in both chicken [Vicario et al.,
Fig. 4. Digital images from two representative organotypic cultures of telencephalic oblique $(\mathbf{a}-\mathbf{d}, \mathbf{g})$ and frontal $(\mathbf{e}-\mathbf{f}, \mathbf{h}-\mathbf{j})$ slices of chicken embryos (c-Al-209 and c-Al-159b; E10), at an intermediate telencephalic level. The fluorescent cell tracker CMFDA (CFDA, green) was centered in the Stv in both cases. The slices were immunolabeled to detect Islet1 ( $\mathbf{a}, \mathbf{d}, \mathbf{f}, \mathbf{g}, \mathbf{i}, \mathbf{j}$; shown in red). Stv-derived cells are seen to reach radially the St and pINP, and tangentially the Ceov $(\mathbf{a}-\mathbf{d}, \mathbf{g})$ and BSTLd $(\mathbf{f}, \mathbf{h}-\mathbf{j})$. The arrows show some examples of cells double labeled for Isletl $(\mathbf{c}, \mathbf{d}, \mathbf{g}-\mathbf{j}$; detail in $\mathbf{c}^{\prime}, \mathbf{d}^{\prime}, \mathbf{g}^{\prime}-\mathbf{j}$ ' taken from squared areas in $\left.\mathbf{c}, \mathbf{d}, \mathbf{g}-\mathbf{j}\right)$. In the BSTLd, Stv-migrating cells overlap the Islet1-rich medial and lateral subdivisions (BSTLdm and BSTLdl; $\mathbf{f}$ ). Scale bar in $\mathbf{c}$ also applies to $\mathbf{d}$, $\mathbf{g}$, bar in $\mathbf{c}^{\prime}$ also applies to $\mathbf{d}^{\prime}, \mathbf{g}^{\prime}$, in $\mathbf{h}$ also to $\mathbf{i}$, $\mathbf{j}$, and in $\mathbf{h}^{\prime}$ also to $\mathbf{i}^{\prime}$, $\mathbf{j}^{\prime}$. See online version for colors and list for abbreviations.

(For figure see next page.)
150
Brain Behav Evol 2015;85:139-169 DOI: $10.1159 / 000381004$ 


\section{Color illustration online only!}
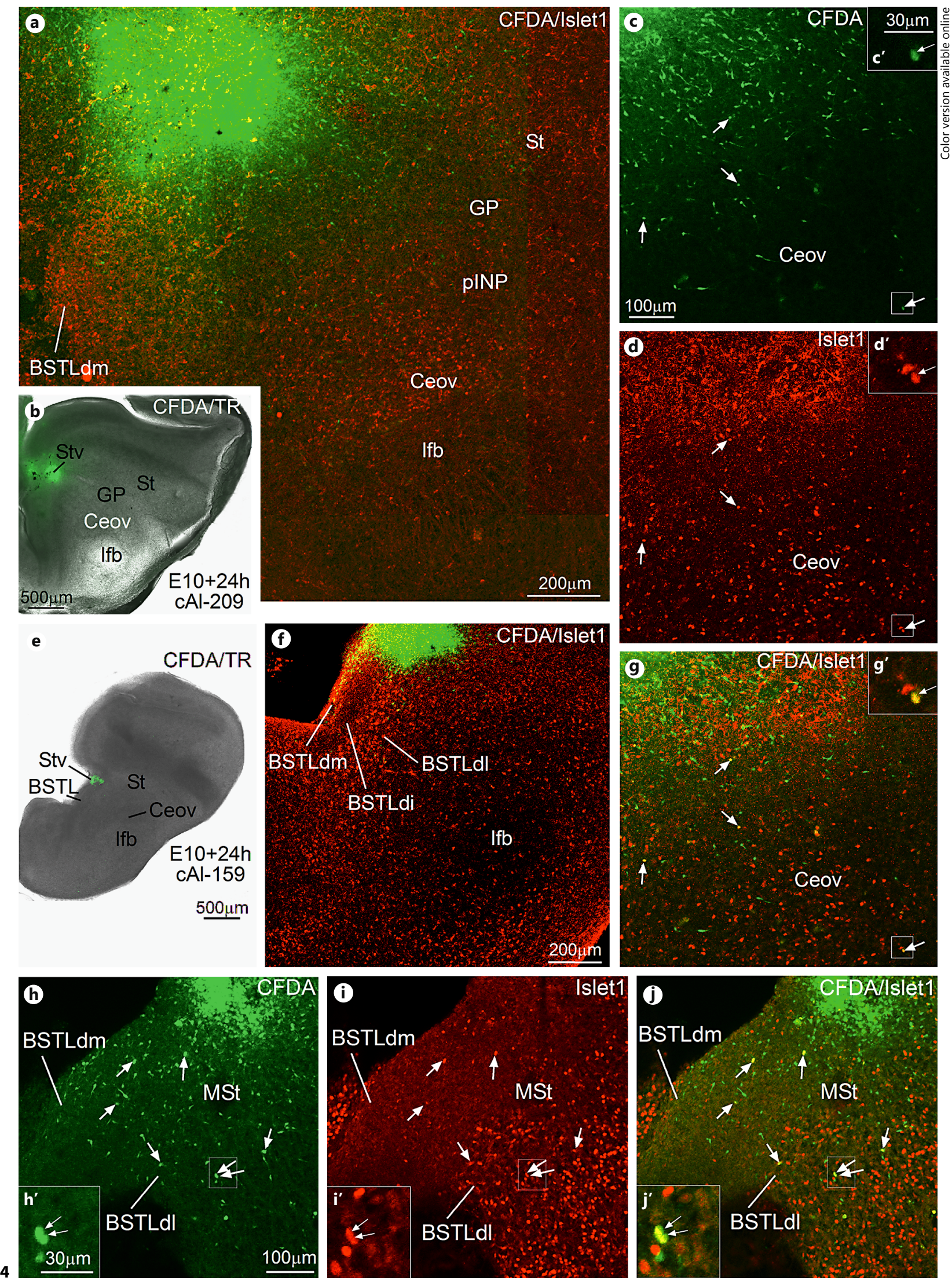
2014; present results] and mice [García-López et al., 2008], which is typical of striatal-like areas [Puelles et al., 2000; Xu et al., 2008]. In contrast, the medial parts of the chicken EAce, comprising the BSTLd and other EAce subdivisions, include numerous cells expressing Nkx2.1 mostly derived from the $\mathrm{Pa}$, but also neuron subpopulations from the Stv (expressing Islet1) and Std (expressing Pax6) [Vicario et al., 2014; present results], resembling the BSTL and adjacent parts of the EAce of mouse [García-López et al., 2008; Bupesh et al., 2011a]. These findings, together with those previously published in different species of mammals, birds and reptiles [Martínez-García et al., 2007; Moreno et al., 2010; Vicario et al., 2014; see other references below], support the homology of the chicken EAce to that of other vertebrates, help to explain the existence of cells with similar phenotype along the mediolateral extension of the cell corridor and reinforce the existence of multiple cell subcorridors inside the EAce, which - although intermingled - keep their special identity, provided by the specific embryonic origin and transcription factor expression of their cells and, consequently, the specific neurotransmitter/neuropeptide content and connections of such cells. We discuss these findings in separate sections below.

\section{The Chicken StC (Intercalated-Like) and the CeC Receive Cells from the Std (Expressing Pax6)}

In previous studies in chicken, we identified two Pax6rich cell groups of the subpallium, the $\mathrm{StC}$ and the $\mathrm{CeC}$, which were comparable to either part of the intercalated amygdalar cells [Abellán and Medina, 2009; Vicario et al., 2014] or the capsular subdivision of the CeA [Vicario et al., 2014] of the mouse, based on their similar position, genetic profile and suggested embryonic origin in the Std (LGEd-like; for the mouse see, Kaoru et al. [2010] and Bupesh et al. [2011a]). Of note, similarly to the mammalian intercalated amygdalar cells [Kaoru et al., 2010], the chicken StC also expresses the transcription factor FoxP2 (fig. 5c') [García-Calero and Scharff, 2013; García-Calero et al., 2013; present results]. Our results from cell migration assays confirmed the presence of cells in the chicken $\mathrm{StC}$ and $\mathrm{CeC}$ that derive from the Std, and at least part of them express Pax6 (fig. 10a, b). Since similar cells also appear to be present in turtles [Moreno et al., 2010], these results support the homology of such Pax6 neuron subpopulations across amniotes, although more data are needed to distinguish between subgroups of Pax6 lineage neurons in different species. In the mouse, there are three subtypes of LGEd-derived cells based on their high or low expression of Pax6 versus FoxP2, and it appears that not all intercalated amygdalar cells expressing FoxP2 show detectable levels of Pax6 [Kaoru et al., 2010]. In our previous study, we also identified some Pax6-rich cell patches intercalated between $\mathrm{CeC}$ and the arcopallial amygdala, and continuous dorsally with the $\mathrm{StC}$, which we also considered a ventral part of the chicken intercalated-like amygdalar cell system (formed dorsally by the StC [Vicario et al., 2014]). Our results from migration assays did not provide enough data to determine whether the Pax6 cells of these ventral intercalated-like patches derive from the Std, although it is likely many of them do, as those of the StC.

In mammals, the intercalated amygdalar cells receive input from the prefrontal cortex and lateral/basolateral pallial amygdala and project to the central amygdala, and are considered an extremely important interface to control central amygdalar outputs and fear responses (expression/recall and extinction) [Paré et al., 2004; Paré and Durvarci, 2012]. It would be interesting to study whether the chicken intercalated-like cells play a similar role to those in mammals. In both mammals [Kaoru et al., 2010] and birds [García-Calero and Scharff, 2013; García-Calero et al., 2013; present results], the intercalated/intercalated-like amygdalar cells express FoxP2, a transcription
Fig. 5. $\mathbf{a}, \mathbf{b}, \mathbf{d}-\mathbf{i}^{\prime}$ Digital images from an organotypic culture of a telencephalic frontal slice of a chicken embryo (c-Al-159c; E10), at an intermediate telencephalic level. The fluorescent cell tracker CMFDA (CFDA, green) was centered in the Std. The slice was immunolabeled to detect Pax6, which helped to confirm the location of the cell tracker application and migrated cells $(\mathbf{e}, \mathbf{f}, \mathbf{h}, \mathbf{i}$; shown in red). c For comparison, similar frontal sections hybridized for Pax6 or FoxP2 are shown in c and ' $\mathbf{c}^{\prime}$, respectively, and help to distinguish the Std domain and the StC (part of the chicken intercalated-like cell patches). b, d Std-derived cells are observed in the $\mathrm{StC}$, apparently arriving there by radial migration (cf. radial glial fiber disposition in fig. 6g). d-f Arrows point to an Std-derived labeled cell that expresses Pax6 (detail in $\mathbf{d}^{\prime}-\mathbf{f}^{\prime}$ taken from the squared areas in $\mathbf{d - f}$ ). In addition to the radial migration, Std-derived cells are observed in ventral parts of the subpallium, reaching ventral parts of the MSt as well as the medial $\mathrm{Pa}(\mathbf{g}-\mathbf{i})$ and apparently arrive there by tangential migration. Some of these Std-derived cells follow the i1 tangential cell corridor described by Vicario et al. [2014] and Abellán and Medina [2009]. g-i Arrows point to examples of colocalization of CMFDA and Pax6 in Stdderived cells of the MSt and $\mathrm{Pa}$ (detail in $\mathbf{g}^{\prime}-\mathbf{i}^{\prime}$ taken from the squared areas in $\mathbf{g - i}$ ). Scale bar in $\mathbf{d}$ also applies to $\mathbf{e}-\mathbf{i}$, and bar in $\mathbf{e}^{\prime}$ also applies to $\mathbf{d}^{\prime}-\mathbf{i}^{\prime}$. See online version for colors and list for abbreviations.
(For figure see next page.)
152
Brain Behav Evol 2015;85:139-169 DOI: $10.1159 / 000381004$
Vicario/Abellán/Medina 


\section{Color illustration online only!}
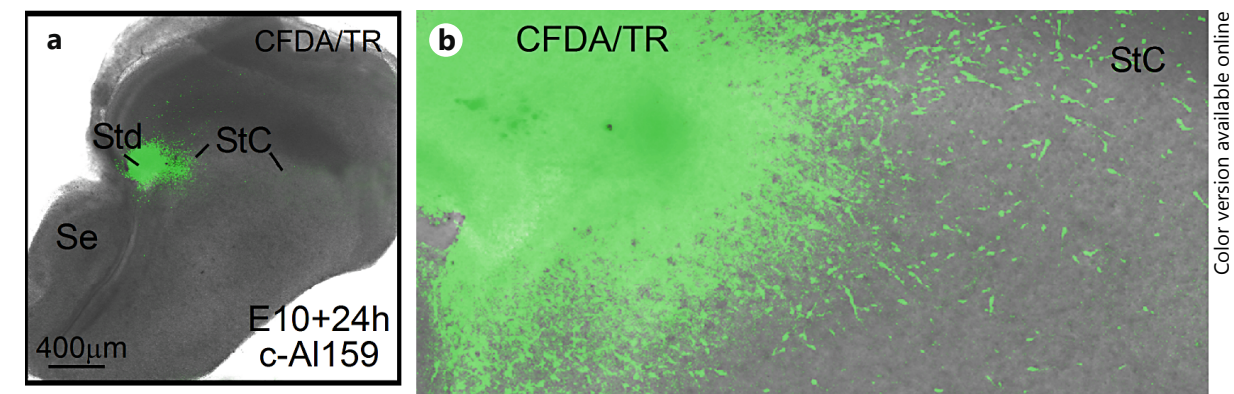

MSt
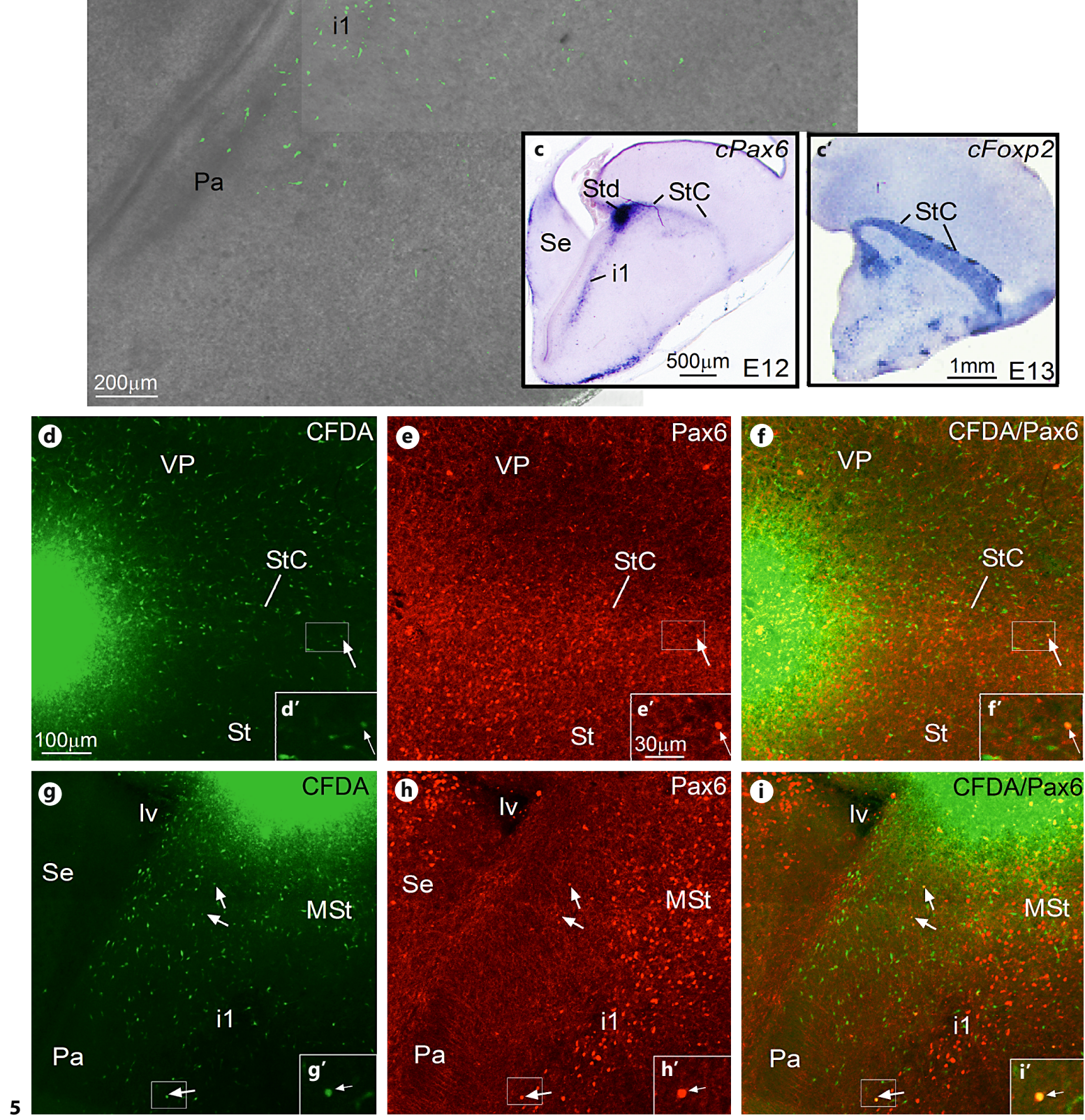

Islet1 and Pax6 Cells of Chicken Central 
factor involved in synaptic plasticity [French and Fisher, 2014; Wohlgemuth et al., 2014] and likely relevant for synaptic rearrangement during the fear extinction process. In addition, our previous data in chicken have shown that some cells of the StC are catecholaminergic, i.e. express tyrosine hydroxylase (TH) mRNA [Vicario et al., 2014]. It is likely that FoxP2 cells and catecholaminergic cells of the ITC derive from the LGEd/Std (fig. 10b), but it is unknown whether they represent the same or different subtypes. In the mouse, the LGEd/Std produce catecholaminergic cells for the olfactory bulb and Tu [Yun et al., 2003], and this is likely similar in other vertebrates [discussed by Abellán and Medina, 2009], but it is unclear whether the mouse LGEd also produces catecholaminergic cells for the ITC [Bupesh et al., 2014]. Moreover, the ITC/ITC-like cells of mammals and birds include subpopulations of neurons containing ENK (chicken: Vicario et al. [2014] and mouse: Bupesh et al. [2011a]; see also the Allen Developing Mouse Brain Atlas [2013]) or dynorphin/prodynorphin (pigeon: see expression in the StC in fig. 2c of Anderson and Reiner [1990a] and mouse: see Allen Developing Mouse Brain Atlas [2013]), which may be produced in the LGEd/Std (fig. 10b).

On the other hand, the CeC of mammals is rich in ENK neurons that appear to project to other parts of the CeA (including the medial subdivision or CeM, which is the major source of long descending projections) and to the BSTL, thus influencing the activity of these centers and their descending pathways to the hypothalamus and brainstem [Poulin et al., 2008; Haubensak et al., 2010]. ENK neurons of the EAce may be involved in nociception and stress-induced analgesia [Kang et al., 1998; reviewed by Poulin et al., 2006, 2008], and are activated following systemic administration of interleukin- $1 \beta$, a cytokine related to inflammatory pain hypersensitivity [Day et al., 1999]. The chicken $\mathrm{CeC}$ is also rich in ENK neurons (expressing pro-ENK mRNA [Vicario et al., 2014]), and based on their distribution similar to those expressing Pax6, it is likely that they represent the same Std-derived neurons (fig. 10b). This has also been suggested for the
ENK neurons of mouse CeC [Bupesh et al., 2011a]. Like the mammalian $\mathrm{CeC}$ [Jolkkonen and Pitkänen, 1998; Cassell et al., 1999; Csáki et al., 2000], the region identified by us as the chicken $\mathrm{CeC}$ likely receives pallial amygdalar input (data on pigeon: Kröner and Güntürkün [1999]) and projects to the BSTL [Atoji et al., 2006] and the paraventricular hypothalamic domain [Vicario et al., 2014]. However, it is unknown whether the cells projecting to the hypothalamus are ENK neurons (all of which are GABAergic; i.e. they contain $\gamma$-aminobutyric acid, GABA [Poulin et al., 2008]) or perhaps are glutamatergic neurons, similarly to mammals [Csáki et al., 2000]. A few glutamatergic cells are present in the region of the chicken $\mathrm{CeC}$, which appear to primarily originate in the caudoventral pallium (fig. 10b) [Abellán and Medina, 2009]. However, we cannot discard that a few of them may have an extratelencephalic origin in the prethalamic eminence (EMT) [Abellán and Medina, 2009; see discussion in Vicario et al., 2014].

\section{Chicken PINP Includes Cells from both the Std}

(Expressing Pax6) and Stv (Expressing Islet1)

In a previous study in chicken, we identified a pINP that resembles the CeL and CeM of mammals based on its position and content of neurons expressing Pax6 or Islet1, suggested to derive either from the Std or Stv, respectively [Vicario et al., 2014]. Our present results from migration assays combined with immunofluorescence corroborate this suggestion, showing that the chicken pINP is indeed populated by numerous cells derived from either the Std or Stv, part of which express Pax6 or Islet1, respectively (fig. 10a, b). In the mouse, the CeL also contains abundant LGEv-derived neurons expressing Islet1 [Waclaw et al., 2010; Bupesh et al., 2011a] and LGEdderived neurons expressing Pax6, with the latter being mainly located in the most lateral parts of the CeL [Bupesh et al., 2011a]. As suggested for the mouse CeL [Bupesh et al., 2011a], it is likely that the Std-derived Pax6 neurons of the chicken pINP contain ENK, while the Stv-derived Islet1 neurons may contain CRF and/or other neuropep-
Fig. 6. a-f, h-k Digital images from two representative organotypic cultures of telencephalic oblique (a-f) and frontal (h-k) slices of chicken embryos (c-Al-211 and c-Al-207; E8.5), at intermediate telencephalic levels. The fluorescent cell tracker CMFDA (CFDA, green) encompassed the Std and part of the Stv in both cases. The slices were immunolabeled to detect Pax6 (c, e, f, j, k; shown in red), which is expressed in Std-derived cells. Std/Stvderived cells are seen in the StC, St and pINP, and many examples of double labeling for Pax6 are seen (arrows in $\mathbf{b}, \mathbf{c}, \mathbf{i}-\mathbf{k}$ ). $\mathbf{d}-\mathbf{f}, \mathbf{i}^{\prime}-\mathbf{k}^{\prime}$
Details (taken from the squared areas in $\mathbf{b}, \mathbf{c}$ and $\mathbf{i}-\mathbf{k}$, respectively) point to examples in the pINP. These double-labeled cells expressing Pax6 specifically derive from the Std. g, g' To distinguish between cells migrating radially or tangentially in the slices shown in this figure and in figure 5 , we show a similar frontal section immunostained for vimentin (using $\mathrm{H} 5$ antibody), which labels radial glial fibers. Scale bar in $\mathbf{b}$ also applies to $\mathbf{c}$, bar in $\mathbf{d}$ also to $\mathbf{e}$, $\mathbf{f}, \mathbf{i}^{\prime}-\mathbf{k}^{\prime}$, and bar in $\mathbf{i}$ also applies to $\mathbf{j}, \mathbf{k}$. See online version for colors and list for abbreviations.
(For figure see next page.)
154
Brain Behav Evol 2015;85:139-169 DOI: $10.1159 / 000381004$
Vicario/Abellán/Medina 


\section{Color illustration online only!}

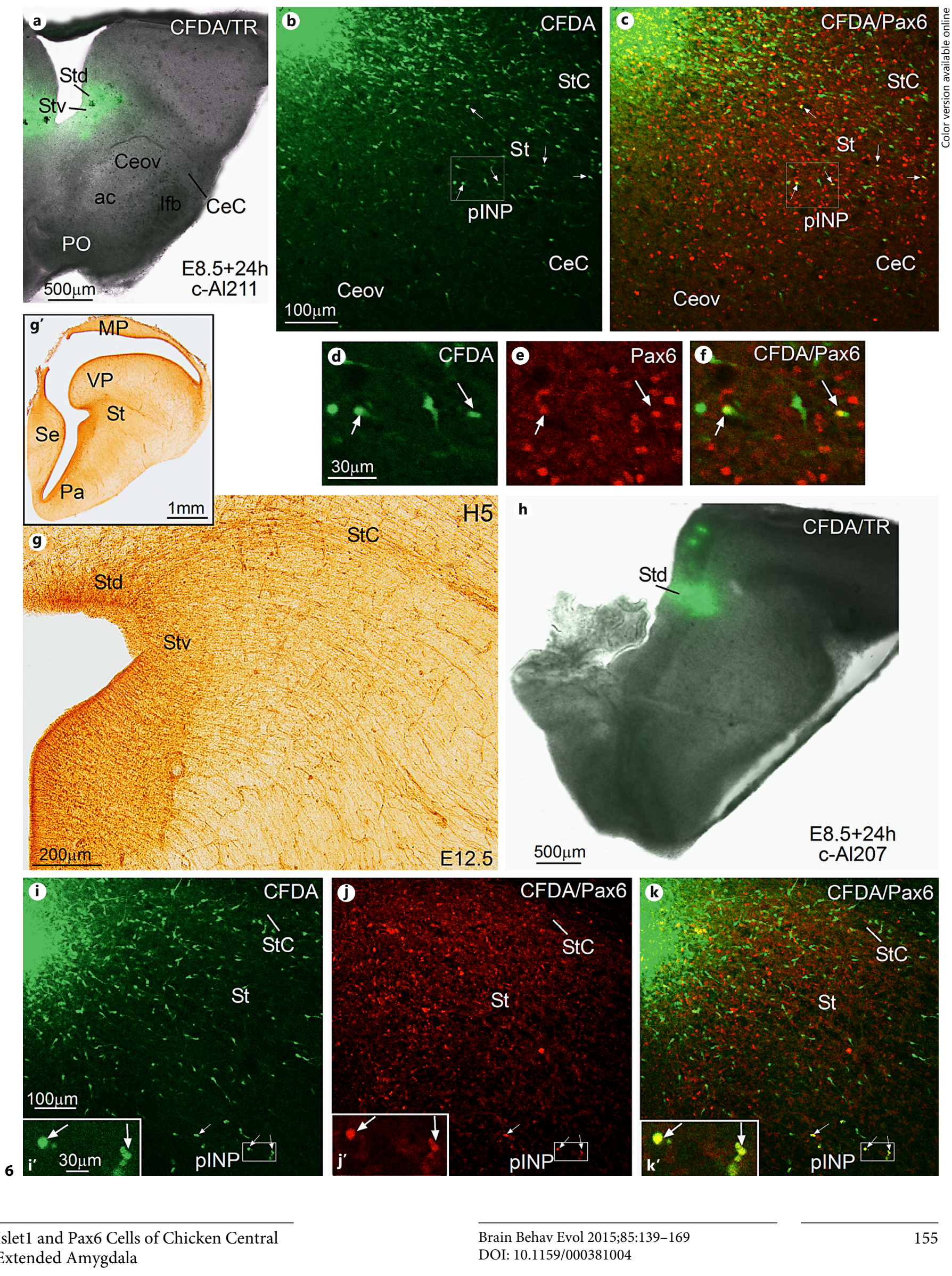


tides and the protein calbindin (CB) found primarily in the CeL but also in the CeM of mammals (CRF and dynorphin [Gray and Magnuson, 1992; Marchant et al., 2007] and CB [Jolkkonen and Pitkänen, 1998; Marchant et al., 2007]) and in the region of pINP in chicken (CRF [Vicario et al., 2014] and CB [Real et al., 2008]; fig. 10b).

Regarding ENK cells, a major part (70\%) of these cells of both $\mathrm{CeL}$ and $\mathrm{CeC}$ in the mouse appear to be protein kinase $C-\delta$ positive [Haubensak et al., 2010]; in this article, $\mathrm{CeL}$ appears to include both the $\mathrm{CeC}$ and CeL. On the other hand, about $10 \%$ of ENK cells of rat CeL coexpress the neuropeptide neurotensin (NT) [Day et al., 1999], suggesting the existence of at least two subtypes of ENK cells. This raises questions on the embryonic origin, evolution and specific connections of each subtype of ENK neurons found in the CeL. For example, the ENK neuron subtypes with or without NT (fig. 10b) may originate in the two different progenitor subdomains of the LGEd described in the mouse by Flames et al. [2007], namely the first and second progenitor subdomains of LGE (pLGE): pLGE1 and pLGE2. Based on the distribution of the cells (pro-ENK [Poulin et al., 2008; Bupesh et al., 2001a] and NT [Allen Developing Mouse Brain Atlas, 2013]), we propose that ENK cells without NT may originate in pLGE1, while ENK/NT cells may originate in pLGE2. Since there are no NT-containing cells in the region of the pINP (neither in $\mathrm{CeC}$ nor Ceov) in chicken and pigeon [Atoji et al., 1996; Esposito et al., 1997], this second ENK neuron subtype may not be present in birds, which correlates with the apparent absence of a pLGE2-like subdomain in chicken [Abellán and Medina, 2009].

Regarding CRF cells (fig. 10b), they overlap the Islet1 cells, but not the Pax6 cells, in the murine CeL [Bupesh et al., 2011a] and pINP (and also Ceov) of chicken [Vicario et al., 2014]. This suggests that these cells originate in the LGEv/Stv [Bupesh et al., 2011a; Vicario et al., 2014]. In the rat, a large part (about two thirds) of CRF cells located in the CeL coexpress dynorphin [Marchant et al., 2007], and this may be similar in chicken, but data on dynorphin in the avian EAce are missing. The murine
$\mathrm{CeL} / \mathrm{CeM}$ also includes a subpopulation of neurons containing NT (rat [Moga and Gray, 1985; Gray and Magnuson, 1992] and mouse [Allen Developing Mouse Brain Atlas, 2013]), the majority of which (80-90\%) coexpress CRF (fig. 10b) [Shimada et al., 1989], but it appears that NT is not expressed in cells of the pINP (nor Ceov) of pigeons and chicken [Atoji et al., 1996; Esposito et al., 1997].

On the other hand, the chicken pINP includes a subpopulation of neurons containing the neuropeptide SOM that may derive from the embryonic Pavc (fig. 10b) [Vicario et al., 2014]. These resemble a similar neuron subpopulation found in the CeL and CeM of the mouse [García-López et al., 2008; Real et al., 2009; Bupesh et al., 2011a] and other mammals [Moga and Gray, 1985; Jolkkonen and Pitkänen, 1998]. In the rat, the majority of SOM cells of the CeM, but not the CeL, coexpress the neuropeptide SP [Shimada et al., 1989], suggesting that there are two distinct subpopulations of SOM neurons in the central amygdala in mammals, and raising questions on the embryonic and evolutionary origins of these two different subpopulations (fig. 10b). Do both subtypes exist in other vertebrates, and do both originate in the same ventrocaudal subdivision of the MGE (MGEvc)/Pavc domain? In the chicken, the embryonic Pavc that appears to produce SOM neurons also seems to produce SP-expressing cells [see fig. 6e, $\mathrm{f}$ in Abellán and Medina, 2009], suggesting that at least part of the SOM cells of the chicken extended amygdala may coexpress SP and originate in Pavc (fig. 10b). However, the avian BSTLd contains notably more SOM cells than SP cells, which in fact are very scarce in this nucleus [Reiner et al., 1983; Anderson and Reiner, 1990b; Abellán and Medina, 2009; Vicario et al., 2014]. Therefore, it is possible that both subpopulations of SOM cells also exist in birds.

In mammals, the CRF and SOM neurons of the CeL show descending projections to the brainstem (periaqueductal gray: Penzo et al. [2014]; parabrachial nucleus: Moga and Gray [1985] and Panguluri et al. [2009], and solitary tract nucleus: Saha et al. [2002]), and appear to be involved in distinct functions: CRF neurons in anxiety responses
Fig. 7. b-i' Digital images from an organotypic culture of a telencephalic frontal slice of a chicken embryo (c-Al-159d; E10), at a caudal telencephalic level. The fluorescent cell tracker CMFDA (CFDA, green) was centered in the Std. The slice was immunolabeled to detect Pax6, which helped to confirm the location of the cell tracker application and migrated cells $(\mathbf{c}, \mathbf{e}, \mathbf{f}, \mathbf{h}$, i; shown in red). a For comparison, a similar frontal section hybridized for cPax6 is shown, enabling the distinction with the Std domain, StC and $\mathrm{CeC}$. Std-derived cells are seen along the $\mathrm{StC}(\mathbf{c}, \mathbf{g}, \mathbf{i})$, possibly arriving by radial migration (as compared with radial glial fiber disposition in a similar section shown in fig. 3c). In addition, Stdderived cells are seen in the pINP and CeC $(\mathbf{d}-\mathbf{i}) . \mathbf{d}-\mathbf{i}$ The arrows point to double-labeled cells for CMFDA and Pax6 in CeC (detail in $\mathbf{d}^{\prime}-\mathbf{f}^{\prime}$ taken from the squared areas in $\mathbf{d}-\mathbf{f}$ ) and pINP (detail in $\mathbf{g}^{\prime}$-i' taken from the squared areas in $\mathbf{g - i}$ ). Scale bar in $\mathbf{d}$ also applies to $\mathbf{e}-\mathbf{i}$ and in $\mathbf{d}^{\prime}$ also to $\mathbf{e}^{\prime}-\mathbf{i}$ '. See online version for colors and list for abbreviations.

(For figure see next page.)
156

Brain Behav Evol 2015;85:139-169 DOI: $10.1159 / 000381004$ 


\section{Color illustration online only!}
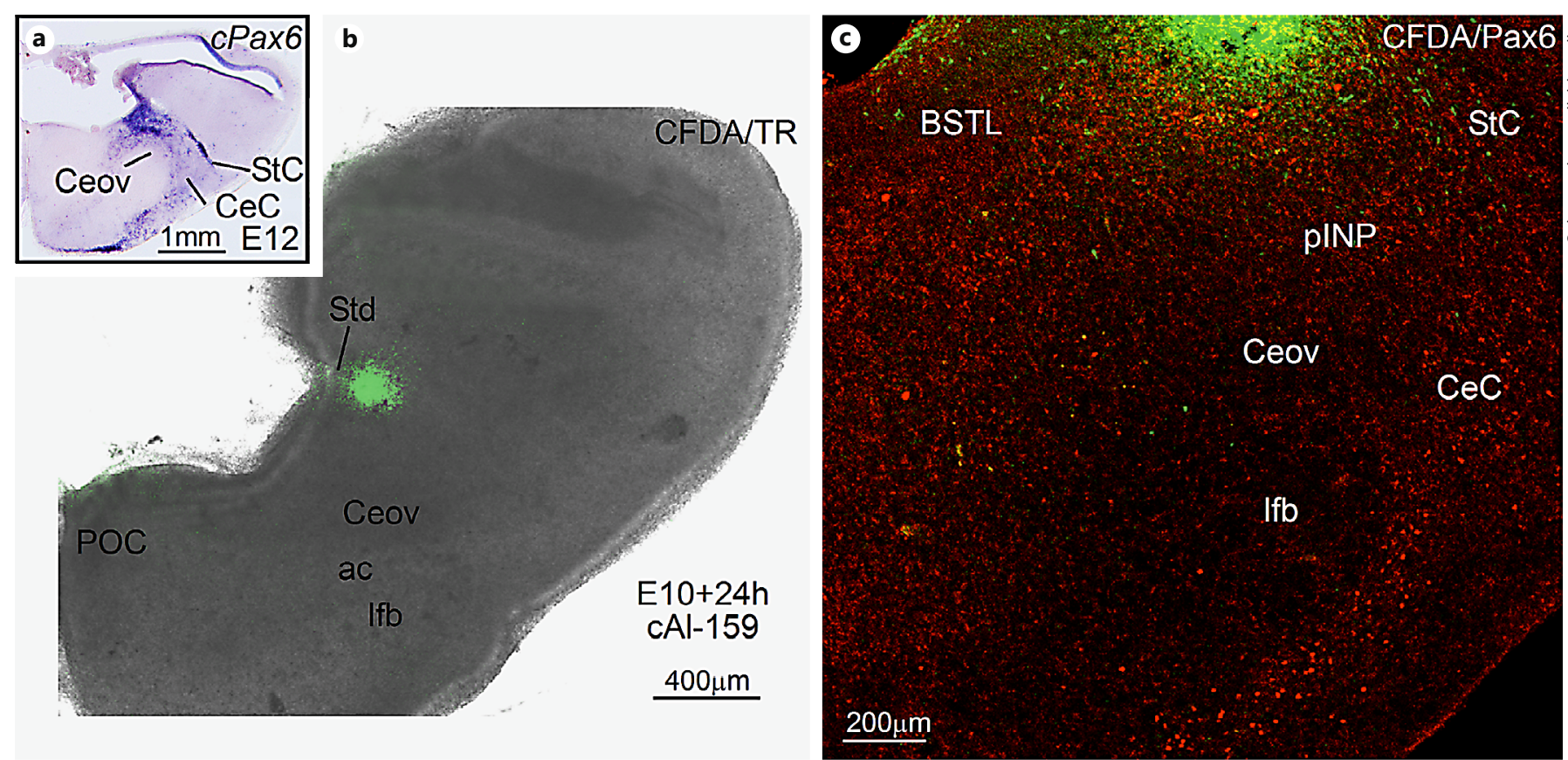

$200 \mu \mathrm{m}$
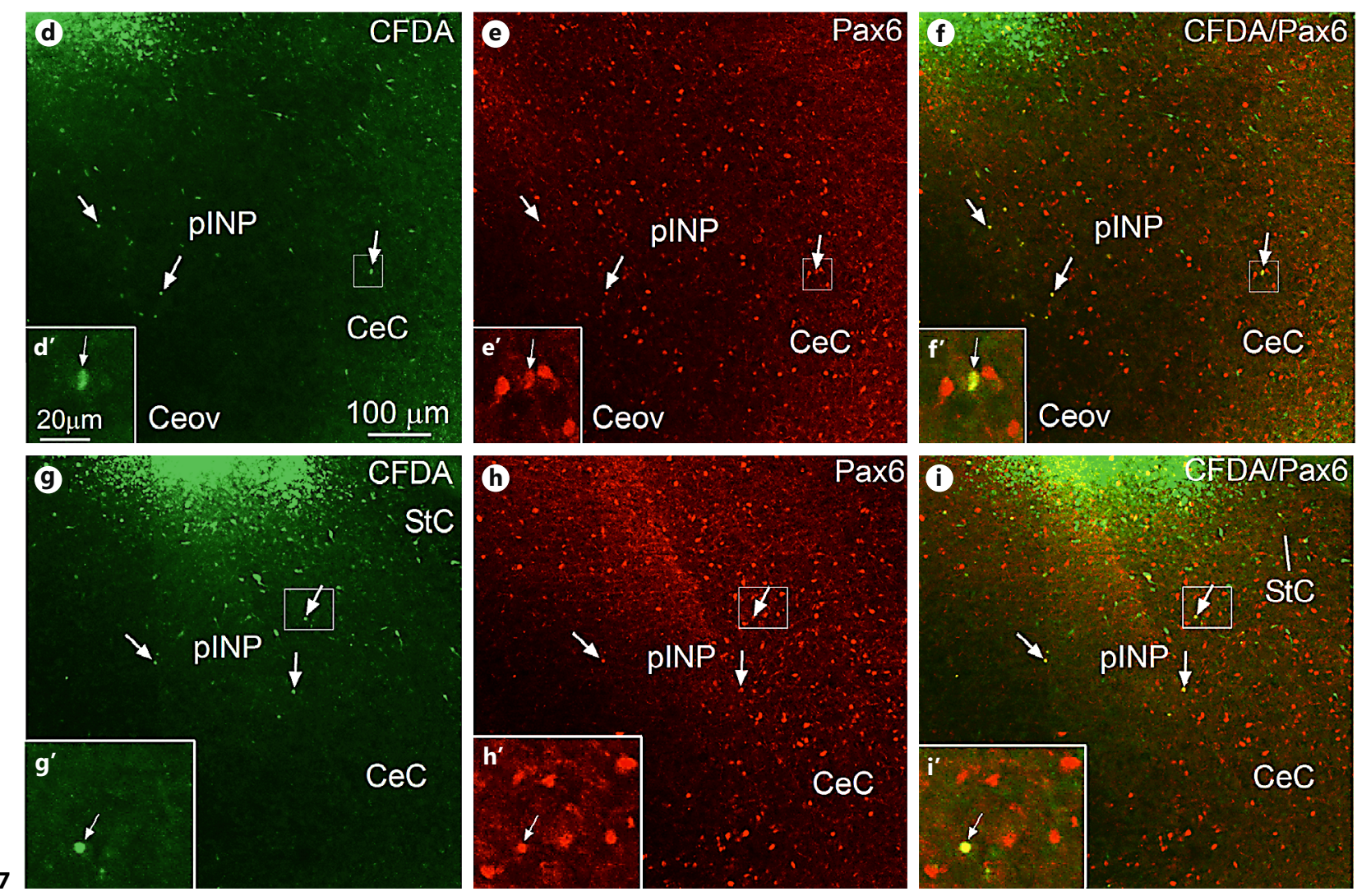

Islet1 and Pax6 Cells of Chicken Central

Brain Behav Evol 2015;85:139-169

DOI: 10.1159/000381004 
[Walker and Davis, 2008; Davis et al., 2010] and SOM neurons in fear learning and expression of conditioned fear responses, which involves memory recall [Li et al., 2013; Penzo et al., 2014]. The SOM neurons of the CeL correspond to the so-called CeL-on cells, which are activated by a conditioned stimulus [Haubensak et al., 2010]. In addition to their direct projections to the brainstem, the CeLon/SOM cells also inhibit the CeL-off cells, thus disinhibiting the CeM output cells [Haubensak et al., 2010]. The CeL-off cells are characterized by the expression of protein kinase C- $\delta$, and $40 \%$ of them contain ENK [Haubensak et al., 2010]. The non-ENK CeL-off cells express oxytocin receptor [Haubensak et al., 2010] and may mediate the effects of oxytocin in decreasing anxiety and stress, and extinction of conditioned avoidance [Huber et al., 2005]. This is explained because oxytocin activates these CeL-off cells, which in turn inhibit the CeM output cells thereby decreasing the fear responses [Huber et al., 2005]. It would be interesting to analyze the expression of oxytocin/mesotocin receptors in the region of the EAce in birds.

On the other hand, the SOM/SP cells of the CeM also appear to project to the periaqueductal gray, based on the projections from SP cells of the CeM reported by Gray and Magnuson [1992], and the extensive coexpression of SP and SOM in CeM neurons shown by Shimada et al. [1989]. However, the exact role of these SP/SOM cells is unknown.

The avian pINP shows connections similar to those of the mammalian CeL/CeM, including input from the pallial amygdala and output to the BSTL [Atoji et al., 2006], paraventricular hypothalamic domain [Vicario et al., 2014] and dorsal vagal complex [Berk, 1987], and may be involved in fear behavior [reviewed by Vicario et al., 2014]. However, connectivity and behavioral studies focusing on the avian pINP, including its different neuronal subpopulations, are urgently needed. These studies should also explore possible projections of different neurons of the pINP to the avian periaqueductal gray [recently redefined by Kingsbury et al., 2011], which in mammals mediates the freezing response and stress-induced analgesia [Behbehani, 1995; Benarroch, 2012].

Fig. 8. a, c-f'"', h Digital images from two organotypic cultures of telencephalic oblique (c-Al-125; E8; a) or frontal (c-Al-135c; E10; h) slices of chicken embryos at caudal telencephalic levels, where the PO part of BSTM (BSTMp) and BSTLd are seen. In both cases, the fluorescent cell tracker CMFDA (CFDA, green) was centered in the PO. b, $\mathbf{g}$, i For comparison, similar sections hybridized for cIslet1 at E9 (b) and E12 (i; expressed in Stv and PO derivatives) or cLhx7/8 at E12 (g; expressed in the commissural PO) are shown.
The Chicken Ceov Is Populated by Stv-Derived Neurons Expressing Islet 1 and Migrate Tangentially to Occupy a More Ventral Position in the Subpallium

In addition to the pINP, we previously identified another nucleus in chicken, the Ceov, which is rich in Islet1 neurons, and we proposed that it is also comparable to the CeL/CeM of rodents [Vicario et al., 2014] and a similar group rich in Isletl cells present in the central amygdala in turtles [see fig. 4a in Moreno et al., 2012a]. Consistent with this proposal, in the present study, we found that the chicken Ceov is populated by cells derived from the Stv, and some of these cells were found to express Islet1 (fig. 10). Since the Ceov is poor in Pax6 cells, this nucleus resembles more closely the mouse CeM, rather than the CeL, since the latter contains a mixture of Pax6 and Islet1 cells [Waclaw et al., 2010; Bupesh et al., 2011a]. However, the chicken Ceov resembles the murine CeL, but differs from the CeM in the following features. The chicken Ceov includes a subpopulation of CRF neurons [Richard et al., 2004; Vicario et al., 2014], which are mostly concentrated in the CeL in rodents (fig. 10b) [Moga and Gray, 1985; Marchant et al., 2007]. As those found in the pINP and CeL, it is likely that CRF cells of the Ceov originate in the Stv. In contrast to the mouse CeM, the chicken Ceov is quite poor in Nkx2.1 neurons of pallido-preoptic origin (see next section) [Vicario et al., 2014; present results], and it is also poor in SOM cells (fig. 10b) [Vicario et al., 2014]. As discussed in a previous study, the connections of the avian Ceov appear to be similar to those of the pINP and resemble those of the mammalian CeL/CeM [Vicario et al., 2014; see discussion above]. However, connectivity and behavioral studies focusing on the avian Ceov are needed.

One curious aspect of the chicken Ceov is that its cells, mostly derived from the Stv and expressing Islet1, appear to migrate tangentially towards a more ventral location in the subpallium, to finally occupy a position just above the lateral branch of the anterior commissure. This is based on the comparison of the final location of the Ceov with: (a) the striatal domain that originates the vast majority of its cells and (b) radial glial fiber disposition (fig. 3b, c, 4a).

In the culture done at E8, after $24 \mathrm{~h}, \mathrm{PO}$-derived cells were seen in the BSTMp and some also reached the caudal pole of the BSTLd (c, d). This slice was immunolabeled to detect Nkx2.1, and cases of double-labeled cells for CMFDA and Nkx2.1 were seen in the BSTMp (arrows in $\mathbf{e}^{\prime}-\mathbf{e}^{\prime \prime \prime}$ ) and BSTLd (arrows in $\mathbf{f}^{\prime}-\mathbf{f}^{\prime \prime \prime}$ ). Scale bar in $\mathbf{c}$ also applies to $\mathbf{d}$, and in $\mathbf{e}^{\prime}$ also to $\mathbf{e}^{\prime \prime}-\mathbf{f}^{\prime \prime \prime}$. See online version for colors and list for abbreviations.

(For figure see next page.)
158

Brain Behav Evol 2015;85:139-169 DOI: $10.1159 / 000381004$ 


\section{Color illustration online only!}
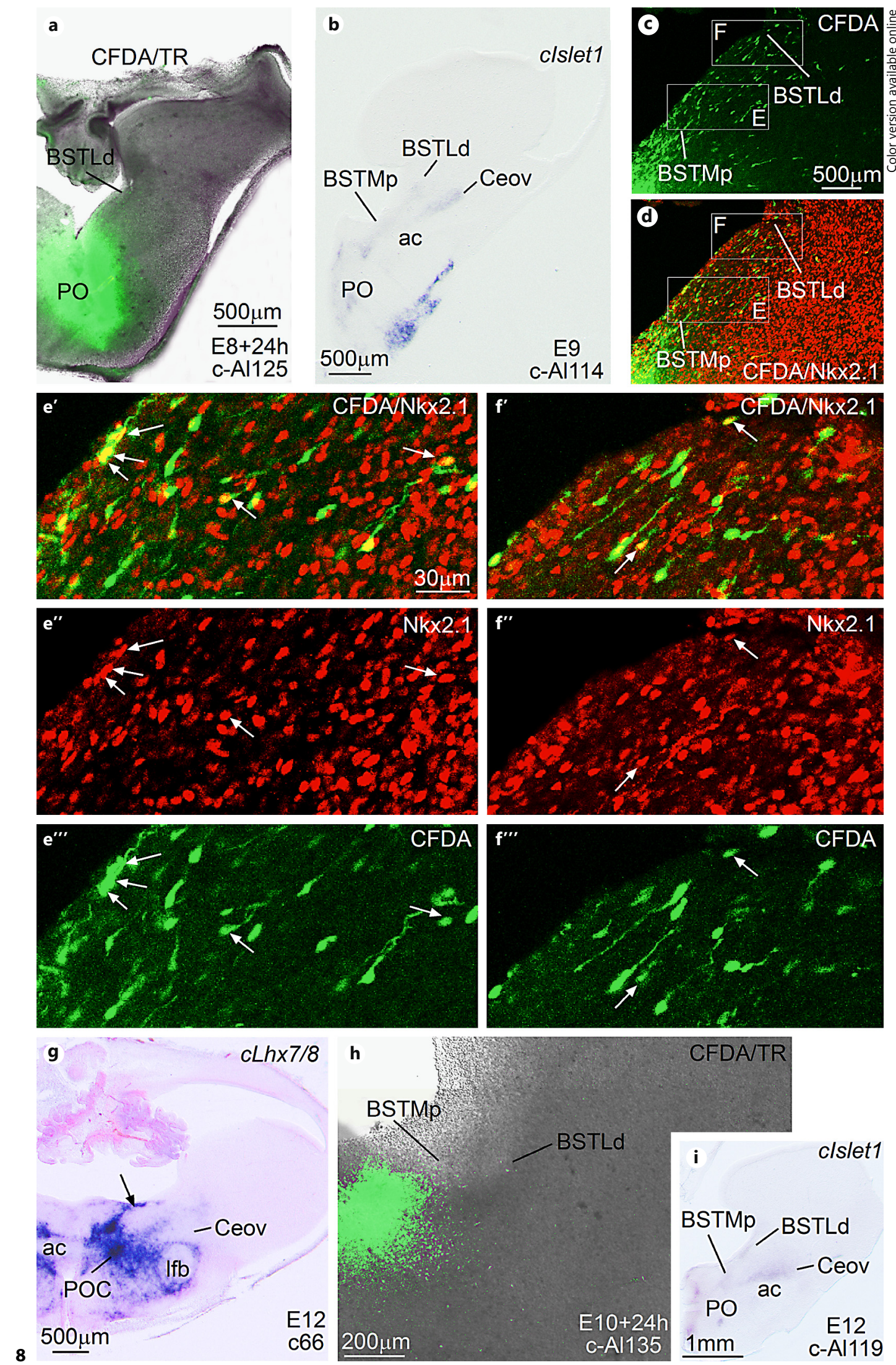

h
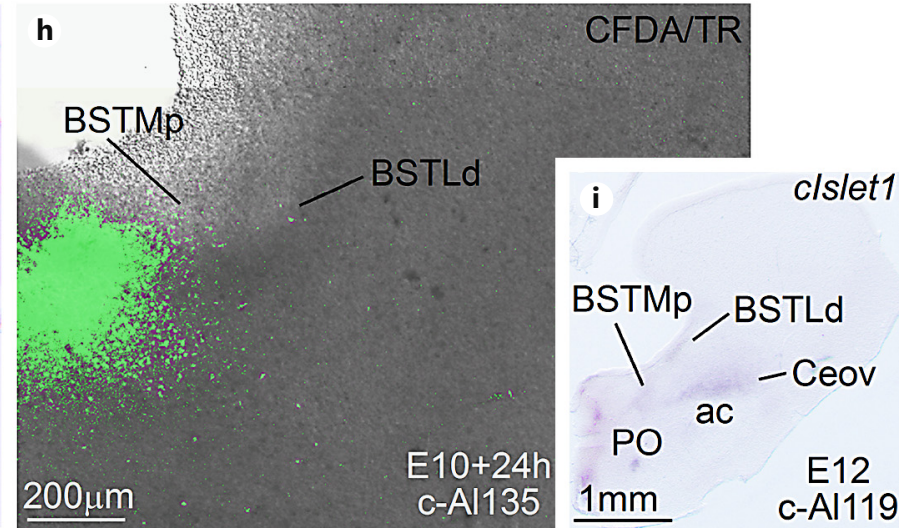
From this comparison, it appears that the Ceov is rather aligned with the radial dorsal part of the $\mathrm{Pa}(\mathrm{Pad})$, which includes the BSTL at a periventricular position (note that the GP is not a reference, since in birds it is displaced dorsally, as explained in Puelles et al. [2007]; Abellán and Medina [2009] and Medina et al. [2014]). It would be interesting to study what led the striatal cells of the Ceov to migrate ventrally during development, and what advantages (if any) this might have implied. For example, this may involve being closer to the trajectory of incoming or descending axons to/from the arcopallial amygdala, which in birds is displaced lateroventrally due to the extraordinary growth of the ventral and caudoventral pallium (nidopallium and arcopallium, respectively). On the other hand, it would be interesting to know whether the striatal cells of the CeA (or part of them) also migrate in a ventral direction in other vertebrates, including other bird species. At periventricular level, groups of Std- and Stv-derived cells migrate in a ventral direction to invade the BSTL part of the EAce in different vertebrates, as explained in the next section.

\section{The Chicken Dorsal BSTL Includes Pallidal and Striatal Cells}

The avian BSTL has been included as part of the avian extended amygdala and was considered comparable to the BSTL of mammals based on its position, chemoarchitecture and connections [Aste et al., 1998; Reiner et al., 2004; Yamamoto et al., 2005; Atoji et al., 2006; Kuenzel et al., 2011], as well as for its similar pallidal origin [Puelles et al., 2000; Abellán and Medina, 2009; Vicario et al., 2014]. A similar group has also been identified in reptiles [Martínez-García et al., 2007, 2008; Moreno et al., 2012a]. Based on their relation to distinct embryonic $\mathrm{Pa}$ subdomains, we proposed the existence of dorsal and ventral subdivisions of the chicken BSTL, with the BSTLd being related to the Pad and being part of the EAce, and the ventral BSTL being related to the Pavc and, as such, being part of the medial extended amygdala or EAme [Abellán and Medina, 2009]. In a more recent study, we followed this scheme and additionally described three distinct subdivisions within the BSTLd: medial (BSTLdm),

Fig. 9. a-f Digital images from two selected oblique sections of chicken embryos (c-Al-129 and c-Al-228; E15), at the level of the Ceov and/or BSTLd, processed for immunofluorescence to detect $\mathrm{Nkx} 2.1$. Note the $\mathrm{Pa}$ and $\mathrm{PO}$ ventricular zone rich in Nkx2.1 (a, b, d) and the high number of Nkx2.1 cells in the GP and BSTLd (b, d). In contrast, the Ceov is very poor in Nkx2.1 cells (b; detailed in intermediate (BSTLdi), and lateral subdivisions (BSTLdl) [Vicario et al., 2014] (see scheme in fig. 10a). These three subdivisions are visible at intermediate and caudal levels in chicken [Vicario et al., 2014] and pigeons [see fig. 2, level A9.00 of Atoji et al., 2006], but not at rostral and very caudal levels [Vicario et al., 2014]. In agreement with our data in developing chicken [Vicario et al., 2014], only the medial (cell compact) and intermediate subdivisions are visible at rostral levels of the BSTLd in adult pigeons [see fig. 2, level A10.00 of Atoji et al., 2006]. While during development all of these subdivisions are adjacent to the ventricular zone of the Pad (expressing Nkx2.1) and include numerous cells expressing Nkx2.1 (presumably pallidal in origin; fig. 10a), we also observed that they include abundant cells expressing either Islet 1 or Pax6 that appeared to originate in Stv or Std, respectively [Vicario et al., 2014]. This was based on the continuity of such cells of the BSTLd with tangentially oriented cell corridors, expressing either Islet1 or Pax6 (St origin) [Vicario et al., 2014]; the Pax6 cell corridor was already noticed by Abellán and Medina [2009]. In the present study, using cell migration assays, we have shown that the chicken BSTLd truly receives cells that migrate tangentially from the Std or Stv (fig. 10a). Moreover, a combination of these experiments with immunofluorescence showed that part of the Std-derived cells of the BSTLd do express Pax6, while part of those derived from the Stv do express Islet1 (fig. 10a). This resembles the BSTL of the mouse, a pallidal structure [Puelles et al., 2000; García-López et al., 2008] receiving immigrant neurons from the striatal division [Bupesh et al., 2011a]. However, the neurons with striatal origin of the mouse BSTL originate primarily from the LGEv and express Islet1, and there is only a minor contribution from the LGEd to the mouse BSTL [Bupesh et al., 2011a]. In contrast, the chicken BSTL contains abundant immigrant neurons from both the Std (Pax6) and Stv (Islet1). Our data show that immigrant cells of striatal origin appear to differentially populate the distinct BSTLd subdivisions: in relative terms, Islet 1 cells are very abundant and densely packed in the BSTLdm; Pax6 cells are by far the most abundant cell type in the BSTLdi (being also more numerous than the $\mathrm{Nkx} 2.1$

c). The pINP contains a moderate amount of Nkx2.1 cells (f), similarly to the lateral St (e), and these cells possibly represent migrating cells mostly derived from the Pa. Scale bar in $\mathbf{b}$ also applies to d, and in $\mathbf{c}$ also to e, f. See online version for colors and list for abbreviations.

(For figure see next page.)
160

Brain Behav Evol 2015;85:139-169 DOI: $10.1159 / 000381004$ 


\section{Color illustration online only!}

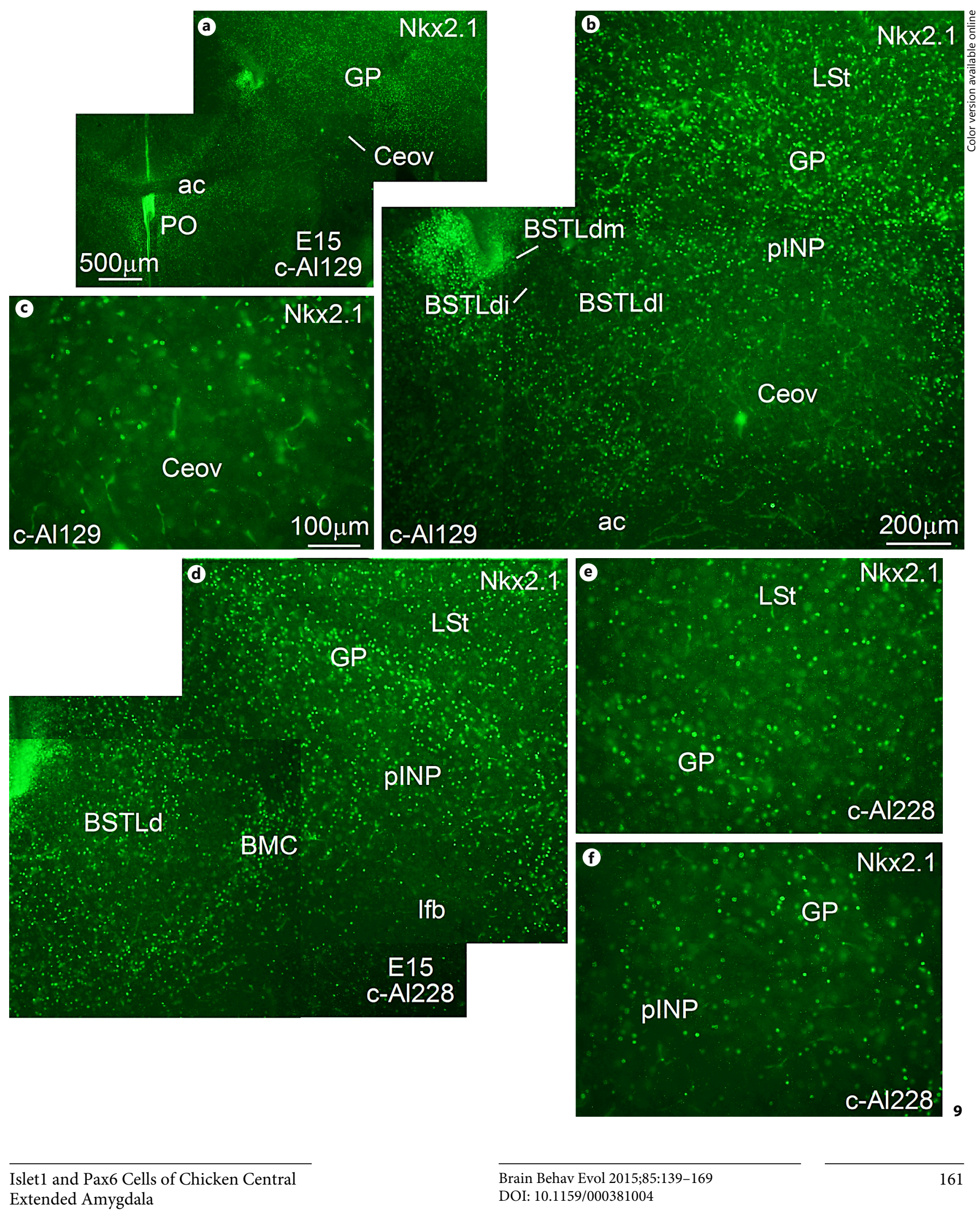


cells); the BSTLdl contains many cells of all types, Pax6,

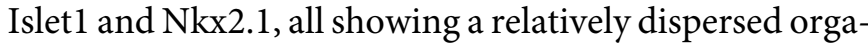
nization [Vicario et al., 2014; present results].

The neuropeptide content of the Pax6 and Islet 1 cells of striatal origin found in the BSTLd is unknown, but based on their origin may be similar to some of those found in the central amygdala, such as ENK or CRF (fig. 10b). Neurons containing these neuropeptides are found in the BSTLd of quail, chicken and pigeon [Reiner et al., 1984; Molnar et al., 1994; Richard et al., 2004; Martínez-García et al., 2008; Abellán and Medina, 2009; Vicario et al., 2014] as well as in the murine BSTL [Moga et al., 1989; Gray and Magnuson, 1992]. In the rat, $90 \%$ of the CRF neurons of the BSTL coexpress NT, while about $80-90 \%$ of the NT cells coexpress CRF [Shimada et al., 1989]. The chicken/pigeon BSTLd also includes a large subpopulation of neurons that contain the neuropeptide NT [Atoji et al., 1996]. However, since NT cells are not found in the central amygdalar subdivisions in pigeon and chicken (pINP, Ceov and CeC) [Atoji et al., 1996] and there is no coexpression of CRF/NT in the avian central amygdala, such coexpression is also unlikely in the avian BSTLd. Given the scarcity of NT cells in the avian St [Atoji et al., 1996], it is possible that NT cells of the avian BSTLd have a pallidal origin (fig. 10b), and this may be similar for at least part of the NT cells without CRF described in the rat BSTL [Shimada et al., 1989].

Fig. 10. a Schematic drawings of frontal telencephalic sections of E8 and E18 chicken embryos showing the main embryonic progenitor zones that produce cells for the EAce in chicken (modified from a scheme shown in fig. 11 of Vicario et al. [2014]). We used the following color code for the embryonic domains and cells derived from them: blue for striatal, pink for $\mathrm{Pa}$ and yellow for preoptic. In this study, we experimentally demonstrate: (1) the Std origin of at least part of the Pax6 cells found in the St, StC, CeC, pINP and BSTLd; (2) the Stv origin of at least part of the Islet 1 cells found in the St, pINP, Ceov and BSTLd, and (3) the PO origin of at least part of the Nkx2.1 cells found in the BSTLd. See text and Vicario et al. [2014] for more details. b Schematic diagram showing the embryonic progenitor zones that seem to produce cells for the EAce in chicken and mice. These include five subpallial domains (two St, two Pa and one PO), one pallial domain, and one extratelencephalic domain (the EMT). These different domains can be distinguished by their topological position and combination of transcription factors. The major contribution comes from two striatal domains (LGEd/Std and LGEv/Stv, which produce either Pax 6 cells or Islet 1 cells) and from two pallidal domains (dorsal subdivision of the MGEd/Pad and MGEvc/Pavc, which produce $\mathrm{Nkx} 2.1$ cells); cells derived from these domains populate in different proportions the subdivisions of the EAce. Based on the correlation between the distribution of the Pax6 and Islet1 cells
In mammals, the CRF neurons of the BSTL show descending projections to brainstem centers controlling autonomic systems (periaqueductal gray, parabrachial nucleus and dorsal vagal complex) [Gray and Magnuson, 1987; Moga et al., 1989; Gray and Magnuson, 1992] and are involved in anxiety (together with CRF cells of the CeL) [Walker and Davis, 2008; Davis et al., 2010], while ENK cells appear to project to other parts of the EAce and may be involved in stress-induced analgesia [Poulin et al., $2006,2008]$. In addition, a recent study in mice has shown that ENK neurons of the BSTL project to the VTA [Kudo et al., 2014] and may play a role in reward [Jennings et al., 2013b]. These projections are GABAergic and end preferentially on nondopaminergic neurons of the VTA, leading to disinhibition of the dopaminergic neurons [Kudo et al., 2014]. In another study, in vivo photostimulation of BSTL GABAergic projections to the VTA produced rewarding and anxiolytic behavior [Jennings et al., 2013b]. Interestingly, our data in chicken suggest that ENK neurons of the BSTLd are highly heterogeneous, and this may be at least partially similar for the ENK cells of the murine BSTL [Day et al., 1999; Bupesh et al., 2011a]; although some ENK cells of the chicken BSTLd appear to have a striatal origin, many of them appear to originate in the embryonic $\mathrm{Pa}$, and a few may originate in the $\mathrm{PO}$ (fig. 10; see next section) [Vicario et al., 2014]. In rats, about $10 \%$ of the ENK cells of the BSTL coexpress NT,

with neurons expressing different neuropeptides (or proteins, such as CB), we suggest that LGEd/Std-derived Pax6 cells give rise to five different neuron subtypes of the EAce, while the LGEv/Stvderived Islet 1 cells give rise to four different subtypes. The subdivisions where the different subpopulations are found in murine (rat and mouse) and birds (chicken and pigeon) are specified below each neuron subtype. In the mouse, we previously showed that the SOM cells of the central amygdala derive from the MGEvc, and this may be similar in chicken. However, there are two subtypes of SOM cells, raising questions on their origin and their functional differences. In chicken and possibly mice, ENK cells found in the BSTL may have at least three different origins, St, Pa and PO, raising questions on their different functions and evolutionary origins. Finally, evidence in different vertebrates point to the existence of very minor subpopulations of glutamatergic neurons in either the BSTL or the CeC. These may come from the EMT or the pallium. This scheme reveals the power of developmental studies to explain neuronal diversity within the EAce, and is useful for designing future studies aiming to understand the evolutionary origin of the different neuron subpopulations (by studying their presence or absence in more species) and the functional networks in which the different subtypes are involved. See online version for colors and list for abbreviations.

(For figure see next page.)
162

Brain Behav Evol 2015;85:139-169 DOI: $10.1159 / 000381004$ 


\section{Color illustration online only!}
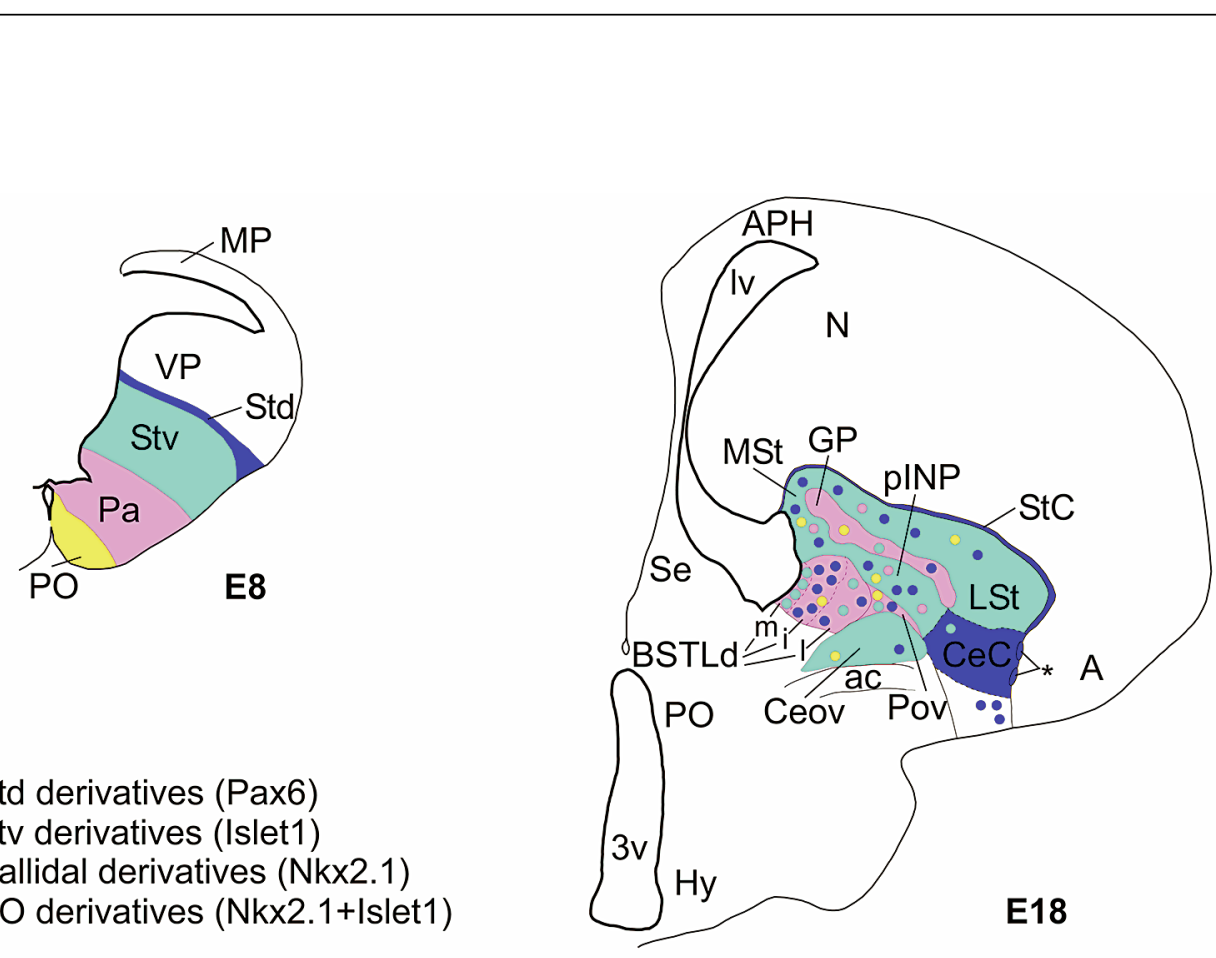

Std derivatives (Pax6)

Stv derivatives (Islet1)

Pallidal derivatives (Nkx2.1)

a

$\mathrm{PO}$ derivatives (Nkx2.1+Islet1)

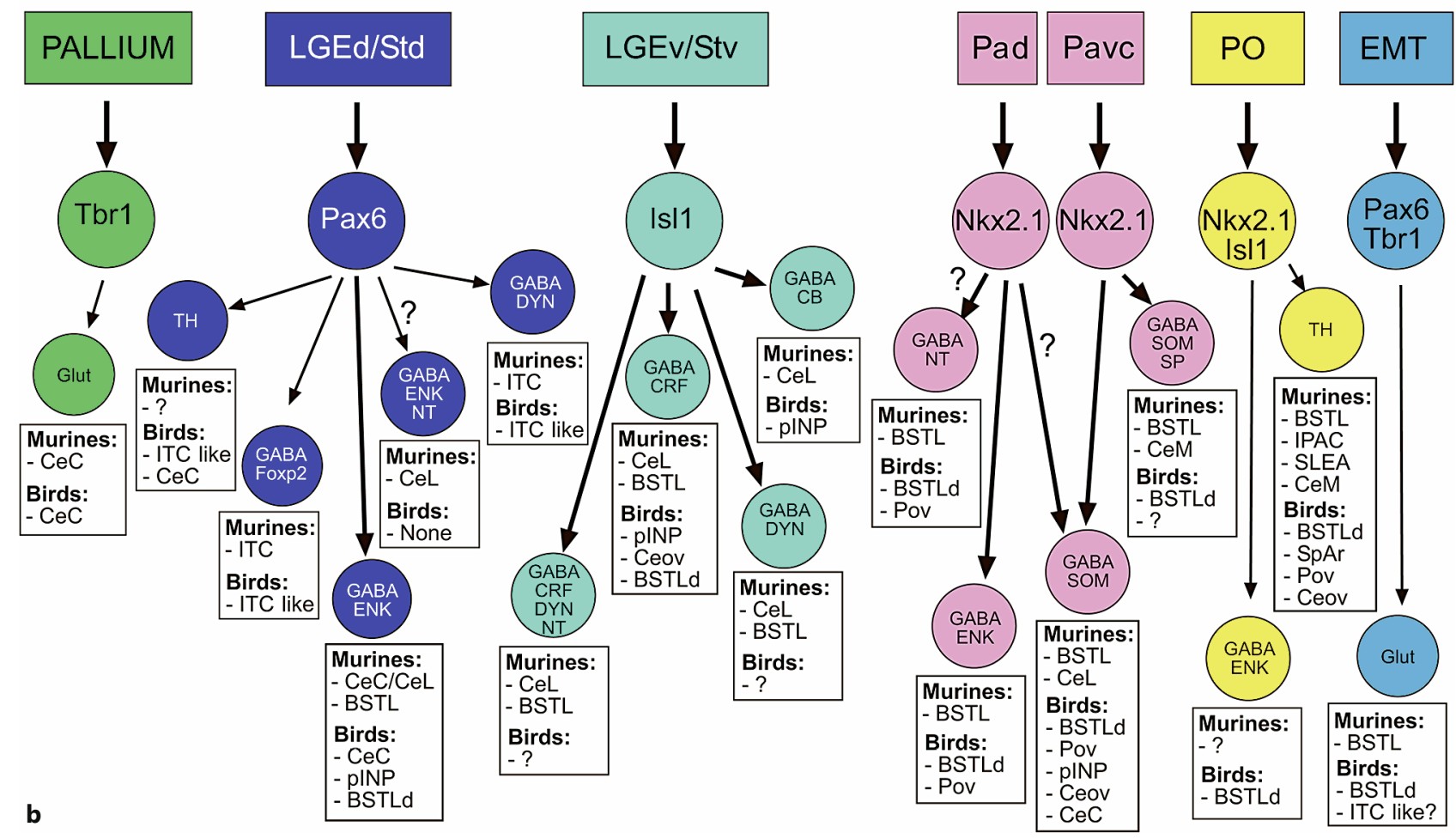


similarly to those in the CeL [Day et al., 1999]. Considering the important role that the BSTL/BSTLd play in anxiety in mammals and birds [Walker and Davis, 2008; Nagarajan et al., 2014], and in reward and aversion functions in mammals [Jennings et al., 2013b] and possibly birds (provided by the BSTL projections to the VTA shown in pigeons [Atoji et al., 2006]), it is mandatory to explore further the differences between these distinct ENK cells in terms of neurochemistry (including receptor expression), connections and functions.

On the other hand, the BSTL/BSTLd of murines and chicken also contain a subpopulation of SOM neurons [Moga et al., 1989; Vicario et al., 2014]. Our data in the mouse [García-López et al., 2008; Bupesh et al., 2011a] and chicken [Vicario et al., 2014] suggest that at least part of these cells may originate in the embryonic Pavc (fig. 10b), which is the same domain that produces SOM cells of the central amygdala in the mouse [García-López et al., 2008; Bupesh et al., 2011a] and possibly chicken [Vicario et al., 2014]. However, in the rat, SOM cells of the BSTL include at least two subpopulations (fig. 10b): one coexpressing SP (located in the ventral subdivision of the BSTL) and another without SP (mostly located in the BSTLd) [Shimada et al., 1989]. Based on our data (discussed above in the pINP section), the SOM/SP subpopulation may be present in the chicken BSTLd and appears to originate in the Pavc (MGEvc-like) domain [Vicario et al., 2014]. Moreover, since SOM cells in the BSTLd are more abundant [Anderson and Reiner, 1990b; Vicario et al., 2014] than SP cells [Reiner et al., 1983; Abellán and Medina, 2009], it is likely that the avian BSTLd also includes a subpopulation of SOM cells without SP, similarly to the mammalian BSTL. In mammals, SOM cells of the BSTL show descending projections to the same brainstem centers that receive the input from SOM neurons of the CeL [Moga and Gray, 1985; Moga et al., 1989; Panguluri et al., 2009], and may gate or modulate fear responses either in series or in parallel (independently) to the cells of the central amygdala (note that the BSTL receives direct input from several pallial structures, including the pallial amygdala, the insular cortex and to some degree from the hippocampal formation [McDonald et al., 1999; Dong et al., 2001a]). In birds, the BSTLd receives inputs from the hippocampus, and pallial and central amygdala, and projects to the same hypothalamic and brainstem centers (VTA, periaqueductal gray, parabrachial nucleus and dorsal vagal complex) as its mammalian homologue (pigeon: Atoji et al. [2006] and rat: Dong et al. [2001a, b] and Dong and Swanson [2003]), but the specific neurons involved in such projections have not been determined.
Although the majority of the neurons of the mammalian BSTL are GABAergic, which is in consonance with their subpallial origin, some studies identified a minor subpopulation of glutamatergic neurons projecting to the VTA [Kudo et al., 2012], which upon activation using in vivo photostimulation leads to angiogenic and aversive functions [Jennings et al., 2013b]. In addition, the output of the BSTL to the hypothalamus, although primarily being GABAergic [Jennings et al., 2013a] (this GABAergic projection reaching the lateral hypothalamus is involved in feeding), also includes a minor subset of glutamatergic projections [Csáki et al., 2000]. The glutamatergic neurons of the murine BSTL are different from the ENK-, CRF- and/or NT-containing cells, since $100 \%$ of the latter are GABAergic [Day et al., 1999], which is typical of cells that originate in the subpallium [Abellán and Medina, 2009]. A minor subpopulation of glutamatergic neurons also appears to be present in the BSTLd of nonmammals [discussed in Vicario et al., 2014] and may at least partially originate in the EMT (see fig. 14M, N of Abellán and Medina [2009] for chicken and Moreno et al. [2010] for turtles). The BSTL cells apparently coming from the EMT also express the transcription factor Pax6 [Abellán and Medina, 2009; discussed in Vicario et al., 2014], suggesting a dual origin of the Pax6 cell population present in this nucleus (fig. 10b).

In conclusion, the BSTL/BSTLd of both mouse and chicken is highly heterogeneous in terms of neuronal subpopulations, and data on their embryonic origin show the existence of more subtypes than simply looking at their neuropeptide content (e.g. ENK cells) or at single transcription factors (e.g. Pax6 cells of the BSTL can be produced in the Std or in the EMT; in the first case, they are GABAergic and in the second glutamatergic). Thus, acknowledging their different embryonic origins is a good starting point for investigating other differences in terms of neurochemistry (including receptor expression), connections and functions, which is essential if we want to understand the role of the BSTL in fear/anxiety [Walker and Davis, 2008; Davis et al., 2010], reward/aversion [Jennings et al., 2013b], ingestion [Jennings et al., 2013a] and stress-induced analgesia [Poulin et al., 2006, 2008].

\section{Cells of PO Origin in the EAce}

In recent years, the embryonic commissural $\mathrm{PO}$, characterized by expression of Nkx2.1, Shh and Lhx7 at the ventricular zone and mantle, has emerged as a major source of neurons for the medial extended amygdala (mouse: García-López et al. [2008], Carney et al. [2010] and Bupesh et al. [2011b] and chicken: Abellán and Me-
164

Brain Behav Evol 2015;85:139-169 DOI: $10.1159 / 000381004$
Vicario/Abellán/Medina 
dina [2008, 2009] and reviews by Medina et al. [2011] and Abellán et al. [2013]). More recently, the embryonic commissural PO was also shown to produce a minor subpopulation of catecholaminergic neurons for the EAce and St in mice [Bupesh et al., 2014], and a similar contribution was also suggested to occur in chicken (fig. 10) [Vicario et al., 2014]. In addition to the putative contribution of catecholaminergic neurons, we recently proposed that the embryonic PO might be the source of a minor subpopulation of enkephalinergic neurons of the chicken BSTLd [Vicario et al., 2014]. Our present data using cell migration assays confirm that, in chicken, the PO produces some cells for the BSTLd, and at least part of these cells contain the transcription factor Nkx2.1 (fig. 10). Thus, it is plausible that some of these cells contain ENK, $\mathrm{TH}$ and/or other phenotypic markers (fig. 10b). Since the PO is also a source of Islet1-expressing neurons (fig. 10b), the possibility also exists that a part of the Islet1 cells of the chicken EAce, especially in the most ventral and caudal subdivisions as the ventrocaudal poles of BSTLd and Ceov, originates in the PO and not in the Stv (discussion in Vicario et al. [2014]). However, our data from migration assays together with the observed ENK expression [Vicario et al., 2014] suggest that the PO contribution to the BSTLd is weak and apparently occurs mainly or exclusively at very caudal levels of this nucleus. In contrast, in our migration assays, we did not see cells of $\mathrm{PO}$ origin invading the Ceov. Moreover, only a very small subpopulation of neurons in the Ceov expresses Nkx2.1 [Vicario et al., 2014; present results]. The PO-related gene Shh expressed in the region of the chicken Ceov at early stages [Abellán and Medina, 2009] (based on this Shh expression, this region was erroneously identified as part of the medial extended amygdala) may be primarily (if not only) related to migratory oligodendrocytes, which specification depends on Shh [Olivier et al., 2001; Spassky et al., 2001]. Therefore, the vast majority of Isletl cells of the Ceov likely comes from the Stv.

Multiple Cell Subcorridors Inside the EAce: Functional Implications and Evolutionary Insights

Based on the different embryonic origin of the neurons of the EAce, together with their gradient-like distribution and inferred phenotype, we previously suggested the existence of at least three cell subcorridors inside the EAce of the mouse [Bupesh et al., 2011a; Medina and Abellán, 2012]. Of these, the first one was related to LGEd-derived neurons expressing Pax6 and possibly ENK, the second was related to LGEv-derived neurons expressing Islet 1 and possibly CRF, and the third was re-

Islet 1 and Pax6 Cells of Chicken Central

Extended Amygdala lated to MGEvc-derived neurons expressing Nkx2.1/ Lhx6 and SOM [Bupesh et al., 2011a]. Our developmental data [Vicario et al., 2014; present results] support the existence of these three subcorridors in the chicken EAce, but based on new evidence of additional embryonic cell origins in both mouse and chicken, we suggest an increase in the number of subcorridors to at least six, with cells that originate in dorsal striatal subdivision (LGEd/ Std), ventral striatal subdivision (LGEv/Stv), Pad, Pavc, PO and EMT (fig. 10b; see details above).

While neurons of the first five subcorridors are presumably GABAergic, as typical in subpallial-derived neurons [Abellán and Medina, 2009; Medina and Abellán, 2012], the neurons derived from the EMT express Tbrl and VGLUT2 and are glutamatergic (fig. 10b) [Puelles et al., 2000; Abellán and Medina, 2009]. Although more studies are needed to further investigate the distribution, molecular profile and connections of the neurons in each subcorridor, with the available data it is tempting to suggest that neurons with the same origin along each subcorridor of the EAce share many molecular and connectivity features, and are possibly involved in the same functional network. A similar suggestion has been raised for neurons of distinct embryonic origin of the medial extended amygdala [García-López et al., 2008; Bupesh et al., 2011b; Medina et al., 2011; Medina and Abellán, 2012; Sokolowski and Corbin, 2012; Abellán et al., 2013]. If proven, developmental data may become essential for helping to unravel the otherwise extremely complex chemical and hodological organization of the EAce, and for understanding its involvement in so many, multifaceted functions (fear/anxiety, feeding/satiety, reward/aversion and pain/analgesia).

Finally, the knowledge on the embryonic origin and molecular profile of the different neuronal subpopulations of the EAce in mice and chicken, together with available data in turtles [Moreno et al., 2010, 2012a, b] and amphibians [Moreno et al., 2009; more references below], is also extremely useful to study the evolution of the different neuronal subpopulations of the EAce, elucidate how cells with different origin/phenotype distribute along the EAce subdivisions in the different species and to understand the adaptive value of each subtype by analyzing species with different ecological niches and specializations. Based on the expression of transcription factors during embryonic development and/or after hatching, it appears that at least the Std-derived Pax6 cells, Stv-derived Islet 1 cells, the Pa-derived Nkx2.1 cells and the EMT-derived Pax6 cells are present in the EAce of turtles [Moreno et al., 2010, 2012a], and were likely present in the EAce of ancestral amniotes. Similarly to the 
mouse and the chicken (see above), the EAce subdivisions of different reptiles appear to include neuronal subpopulations expressing pro-ENK [Reiner, 1987], which may derive from distinct subpallial subdivisions, as suggested for the mouse and chicken. However, more comparative data in different sauropsids are needed in order to understand what was the ancestral condition in amniotes. On the other hand, the Stv-derived Islet 1 cells, the Pa-derived Nkx2.1 cells and the EMT-derived Pax6 cells are present in the EAce of different amphibians, and were likely present in ancestral tetrapods [Moreno and González, 2006; Moreno et al., 2008a, b; Moreno et al., 2012b]. However, based on the available data (e.g. Moreno et al. [2012b] for the BST), the EAce of amphibians does not appear to include the Std-derived and PO-derived cells [Moreno et al., 2008a; Domínguez et al., 2010; Moreno et al., 2012b], although the caudal parts of the BST include a few catecholaminergic neurons [Moreno et al., 2012b] that resemble those found in the EAce of the mouse and chicken with putative preoptic origin [Bupesh et al., 2014; Vicario et al., 2014]. Based on the combination of transcription factors involved in the development of either GABAergic (Dlx and Mash1) or glutamatergic (Tbr1, NeuroD and Neurogenin 2) cells, together with the expression of GABAergic markers (including the enzyme glutamic acid decarboxylase) [Osorio et al., 2010], the subpallial-derived neurons of the amphibian EAce (which make up the majority of the EAce cells, as in other tetrapods) are GABAergic, while those coming from the EMT or the pallium are glutamatergic [Brox et al., 2003, 2004; Wullimann et al., 2005; Moreno et al., 2012b]. In mammals, birds and possibly reptiles, the subpallial-derived GABAergic neurons of the EAce typically contain different neuropeptides, depending on the specific origin (as noted above). In amphibians, neurons expressing pro-ENK have been found in the region of the central amygdala and BST [Merchenthaler et al., 1989], and these may correspond to the Pa-derived subpopulation present in amniotes, although we cannot discard that some may originate in the Stv. Thus, the presence of enkephalinergic cells in the EAce appears to be a common feature of the EAce in tetrapods, but amphibians seem to lack two of the subtypes of enkephalinergic neurons present in mouse, chicken and possibly reptiles: those suggested to derive from the LGEd/Std and those suggested to derive from the PO. On the other hand, CRF neurons (apparently derived from the LGEv/Stv in mouse and chicken) have not been found in the EAce region of turtles [López-Avalos et al., 1993], while data in anurans are inconsistent (not found in the toad [Matsuda et al., 2010] but found in a similar pattern to that in chicken in Xeno- pus laevis [Yao et al., 2004]). Moreover, NT cells have not been found in the EAce of either frogs or lacertid lizards [Bello et al., 1994]. Given the scarcity of information on neuropeptides and the inconsistency in the reports on CRF in the telencephalon in some of the groups, more studies in different species of reptiles and amphibians using in situ hybridization are needed, since this technique is more sensitive to differences in expression.

In summary, available data point to the existence of neurons with at least three different embryonic origins and genetic profiles in amphibians, extending to four or more in reptiles, and six or more in some mammals and birds. Since each main embryonic domain may produce more than one neuron subtype (at distinct progenitor subdomains and/or at different developmental times), the number of different neuron subpopulations increases until at least seventeen or more (fig. 10b). More comparative data of the EAce in different species are needed in order to understand the evolutionary origin of the different cell subtypes of the EAce, and to know whether some of the neuronal subpopulations present in mammals and birds are homologous (derived from similar ones present in the common ancestor) or have originated by independent evolution. Based on the known connections of the central amygdala and BSTL/BST in amphibians, reptiles and birds, it appears that, similarly to mammals, these structures are able to control or modulate fear responses in these vertebrates [Martínez-García et al., 2007, 2008; Moreno et al., 2009, 2012b]. In agreement with this, a significant increase in the activation of neurons has been observed in some subdivisions of the EAce following stress treatment in chicken and frogs (avian BSTL [Nagarajan et al., 2014] and frog BST [Yao et al., 2004]). However, only analyses of the cells of each different corridor will help to understand the neurobiological basis of the multifaceted functions of the EAce, and their differences between different species.

\section{Acknowledgments}

We deeply thank Dr. Ester Desfilis (University of Lleida) for reading the paper and providing useful suggestions for improving the text. We also thank Dr. Agustín Gonzalez (Complutense University of Madrid) for allowing us to use his Olympus microscope to obtain the immunofluorescence images of Nkx2.1 depicted in figure 9 of this paper.

L.M. was supported by the Spanish Ministry of Economy and Competitivity and the Fondo Europeo de Desarrollo Regional (grant no. BFU2012-33029). A.V. received a predoctoral fellowship (No. BES-2010-038400) from the Spanish Ministry of Science and Innovation.
166

Brain Behav Evol 2015;85:139-169 DOI: $10.1159 / 000381004$
Vicario/Abellán/Medina 


\section{References}

-Abellán A, Desfilis E, Medina L (2013): The olfactory amygdala in amniotes: an evo-devo approach. Anat Rec (Hoboken) 296:1317-1332.

-Abellán A, Medina L (2008): Expression of cLhx6 and cLhx7/8 suggests a pallido-pedunculopreoptic origin for the lateral and medial parts of the avian bed nucleus of the stria terminalis. Brain Res Bull 75:299-304.

-Abellán A, Medina L (2009): Subdivisions and derivatives of the chicken subpallium based on expression of LIM and other regulatory genes and markers of neuron subpopulations during development. J Comp Neurol 515:465501.

-Abellán A, Vernier B, Rétaux S, Medina L (2010): Similarities and differences in the forebrain expression of Lhx1 and Lhx 5 between chicken and mouse: insights for understanding telencephalic development and evolution. J Comp Neurol 518:3512-3528.

Alheid GF, Heimer L (1988): New perspectives in basal forebrain organization of special relevance for neuropsychiatric disorders: the striatopallidal, amygdaloid, and corticopetal components of substantia innominata. Neuroscience 27:1-39.

- Alheid GF, Shammah-Lagnado SJ, Beltramino CA (1999): The interstitial nucleus of the posterior limb of the anterior commissure: a novel layer of the central division of extended amygdala. Ann NY Acad Sci 877:645-654.

Alifragis P, Parnavelas JG, Nadarajah B (2002): A novel method of labeling and characterizing migrating neurons in the developing central nervous system. Exp Neurol 174:259-265.

Allen Developing Mouse Brain Atlas $\left.\left({ }^{(}\right) 2013\right)$. Seattle, Allen Institute for Brain Science, http:// developingmouse.brain-map.org.

-Anderson KD, Reiner A (1990a): Extensive cooccurrence of substance $\mathrm{P}$ and dynorphin in striatal projection neurons: an evolutionarily conserved feature of basal ganglia organization. J Comp Neurol 295:339-369.

-Anderson KD, Reiner A (1990b): Distribution and relative abundance of neurons in the pigeon forebrain containing somatostatin, neuropeptide Y, or both. J Comp Neurol 299: 261-282.

-Aste N, Balthazart J, Absil P, Grossmann R, Mühlbauer E, Viglietti-Panzica C, Panzica GC (1998): Anatomical and neurochemical definition of the nucleus of the stria terminalis in Japanese quail (Coturnix japonica). J Comp Neurol 396: 141-157.

Atoji Y, Saito S, Wild JM (2006): Fiber connections of the compact division of the posterior pallial amygdala and lateral part of the bed nucleus of the stria terminalis in the pigeon (Columba livia). J Comp Neurol 499:161182.

Atoji Y, Shibata N, Yamamoto Y, Suzuki Y (1996): Distribution of neurotensin-containing neurons in the central nervous system of the pigeon and the chicken. J Comp Neurol 375: 187-211.
Basyuk E, Bertrand E, Journot L (2000): Alkaline fixation drastically improves the signal of in situ hybridization. Nucleic Acids Res 28:E46.

Behbehani MM (1995): Functional characteristics of the midbrain periaqueductal gray. Prog Neurobiol 46:575-605.

Bello AR, Milán J, Anglade I, Martín A, Negrín I, Díaz C, Conlon JM, Tramu G, Kah O (1994): Comparative distribution of neurotensin-like immunoreactivity in the brain of a teleost (Carassius auratus), an amphibian (Hyla meridionalis), and a reptile (Gallotia galloti). J Comp Neurol 348:511-530.

Benarroch EE (2012): Periaqueductal gray: an interface for behavioral control. Neurology 78: 210-217.

Berk ML (1987): Projections of the lateral hypothalamus and bed nucleus of the stria terminalis to the dorsal vagal complex in the pigeon. J Comp Neurol 260:140-156.

Boardman PE, Sanz-Ezquerro J, Overton IM, Burt DW, Bosch E, Fong WT, Tickle C, Brown WRA, Wilson SA, Hubbard SJ (2002): A comprehensive collection of chicken cDNAs. Curr Biol 12:1965-1969.

Brox A, Puelles L, Ferreiro B, Medina L (2003): Expression of the genes GAD67 and Distalless-4 in the forebrain of Xenopus laevis confirms a common pattern in tetrapods. J Comp Neurol 461:370-393.

Brox A, Puelles L, Ferreiro B, Medina L (2004): Expression of the genes Emx1, Tbr1, and Eomes (Tbr2) in the telencephalon of Xenopus laevis confirms the existence of a ventral pallial division in all tetrapods. J Comp Neurol 474:562-577.

Bupesh M, Abellán A, Medina L (2011a): Genetic and experimental evidence supports the continuum of the central extended amygdala and a multiple embryonic origin of its principal neurons. J Comp Neurol 519:3507-3531.

-Bupesh M, Legaz I, Abellán A, Medina L (2011b): Multiple telencephalic and extratelencephalic embryonic domains contribute neurons to the medial extended amygdala. J Comp Neurol 519:1505-1525.

Bupesh M, Vicario A, Abellán A, Desfilis E, Medina L (2014): Dynamic expression of tyrosine hydroxylase mRNA and protein in neurons of the striatum and amygdala of mice, and experimental evidence of their multiple embryonic origin. Brain Struct Funct 219: 751-776.

Carney RS, Mangin JM, Hayes L, Mansfield K, Sousa VH, Fishell G, Machold RP, Ahn S, Gallo V, Corbin JG (2010): Sonic hedgehog expressing and responding cells generate neuronal diversity in the medial amygdala. Neural Dev 5:14.

Cassell MD, Freedman LJ, Shi C (1999) The intrinsic organization of the central extended amygdala. Ann NY Acad Sci 877:217-241.

Ciocchi S, Herry C, Grenier F, Wolff SB, Letzkus JJ, Vlachos I, Ehrlich I, Sprengel R, Deisseroth K, Stadler MB, Müller C, Lüthi A (2010): En- coding of conditioned fear in central amygdala inhibitory circuits. Nature 468:277-282.

Csáki A, Kocsis K, Halász B, Kiss J (2000): Localization of gutamatergic/aspartatergic neurons projecting to the hypothalamic paraventricular nucleus studied by retrograde transport of $\left[{ }^{3} \mathrm{H}\right] \mathrm{D}$-aspartate autoradiography. Neuroscience 101:637-655.

Davis M, Walker DL, Miles L, Grillon C (2010): Phasic vs sustained fear in rats and humans: role of the extended amygdala in fear vs anxiety. Neuropsychopharmacology 35:105-135.

Day HE, Curran EJ, Watson SJ Jr, Akil H (1999) Distinct neurochemical populations in the rat central nucleus of the amygdala and bed nucleus of the stria terminalis: evidence for their selective activation by interleukin-1-beta. J Comp Neurol 413:113-128.

de Olmos JS, Beltramino CA, Alheid G (2004): Amygdala and extended amygdala of the rat: a cytoarchitectonical, fibroarchitectonical, and chemoarchitectonical survey; in Paxinos G (ed): The Rat Nervous System, ed 3. Amsterdam, Elsevier-Academic Press, pp 509603.

Domínguez L, González A, Moreno N (2010): Sonic hedgehog expression during Xenopus laevis forebrain development. Brain Res 1347: 19-32.

Dong HW, Petrovich GD, Swanson LW (2001a): Topography of projections from amygdala to bed nuclei of the stria terminalis. Brain Res Rev 38:192-246.

Dong HW, Petrovich GD, Watts AG, Swanson LW (2001b): Basic organization of projections from the oval and fusiform nuclei of the bed nuclei of the stria terminalis in adult rat brain. J Comp Neurol 436:430-455.

Dong HW, Swanson LW (2003): Projections from the rhomboid nucleus of the bed nuclei of the stria terminalis: implications for cerebral hemisphere regulation of ingestive behaviors. J Comp Neurol 463:434-472.

Esposito V, De Girolamo P, Gargiulo G (1997): Neurotensin-like immunoreactivity in the brain of the chicken, Gallus domesticus. J Anat 191:537-546.

Flames N, Pla R, Gelman DM, Rubenstein JL, Puelles L, Marín O (2007): Delineation of multiple subpallial progenitor domains by the combinatorial expression of transcriptional codes. J Neurosci 27:9682-9695

French CA, Fisher SE (2014): What can mice tell us about Foxp2 function? Curr Opin Neurobiol 28C:72-79.

Fox RJ, Sorenson CA (1994): Bilateral lesions of the amygdala attenuate analgesia induced by diverse environmental challenges. Brain Res 648:215-221.

García-Calero E, Bahamonde O, Martinez S (2013): Differences in number and distribution of striatal calbindin medium spiny neurons between a vocal-learner (Melopsittacus undulatus) and a non-vocal learner bird (Colinus virginianus). Front Neuroanat 7:46.
Islet1 and Pax6 Cells of Chicken Central Extended Amygdala
Brain Behav Evol 2015;85:139-169

DOI: $10.1159 / 000381004$ 
García-Calero E, Scharff C (2013): Calbindin expression in developing striatum of zebra finches and its relation to the formation of area X. J Comp Neurol 521:326-341.

-García-López M, Abellán A, Legaz I, Rubenstein JL, Puelles L, Medina L (2008): Histogenetic compartments of the mouse centromedial and extended amygdala based on gene expression patterns during development. J Comp Neurol 506:46-74.

-Gray TS, Magnuson DJ (1987): Neuropeptide neuronal efferents from the bed nucleus of the stria terminalis and central amygdaloid nucleus to the dorsal vagal complex in the rat. J Comp Neurol 262:365-374

Gray TS, Magnuson DJ (1992): Peptide immunoreactive neurons in the amygdala and the bed nucleus of the stria terminalis project to the midbrain central gray in the rat. Peptides 13 : 451-460.

-Hamburger V, Hamilton HL (1951): A series of normal stages in the development of the chick embryo. Dev Dyn 195:231-272

-Haubensak W, Kunwar PS, Cai H, Ciocchi S, Wall NR, Ponnusamy R, Biag J, Dong HW, Deisseroth K, Callaway EM, Fanselow MS, Lüthi A, Anderson DJ (2010): Genetic dissection of an amygdala microcircuit that gates conditioned fear. Nature 468:270-276.

-Herman JP, Victor JC, Sanes JR (1993): Developmentally regulated and spatially restricted antigens of radial glial cells. Dev Dyn 197:307-318.

-Higgins GA, Schwaber JS (1983): Somatostatinergic projections from the central nucleus of the amygdala to the vagal nuclei. Peptides 4:657662.

Huber D, Veinante P, Stoop R (2005): Vasopressin and oxytocin excite distinct neuronal populations in the central amygdala. Science 308 : 245-248.

- Jennings JH, Rizzi G, Stamatakis AM, Ung RL, Stuber GD (2013a): The inhibitory circuit architecture of the lateral hypothalamus orchestrates feeding. Science 341:1517-1521.

- Jennings JH, Sparta DR, Stamatakis AM, Ung RL, Pleil KE, Kash TL, Stuber GD (2013b): Distinct extended amygdala circuits for divergent motivational states. Nature 496:224-228.

-Jolkkonen E, Pitkänen A (1998): Intrinsic connections of the rat amygdaloid complex: projections originating in the central nucleus. J Comp Neurol 395:53-72.

-Kang W, Wilson MA, Bender MA, Glorioso JC, Wilson SP (1998): Herpes virus-mediated preproenkephalin gene transfer to the amygdala is antinociceptive. Brain Res 792:133-135.

-Kaoru T, Liu FC, Ishida M, Oishi T, Hayashi M, Kitagawa M, Shimoda K, Takahashi H (2010): Molecular characterization of the intercalated cell masses of the amygdala: implications for the relationship with the striatum. Neuroscience 166:220-230.

Kawakami A, Kimura-Kawakami M, Nomura T, Fujisawa H (1997): Distributions of PAX6 and PAX7 proteins suggest their involvement in both early and late phases of chick brain development. Mech Dev 66:119-130.
Kingsbury MA, Kelly AM, Schrock SE, Goodson JL (2011): Mammal-like organization of the avian midbrain central gray and a reappraisal of the intercollicular nucleus. PLoS One 6:e20720.

Kröner S, Güntürkün O (1999): Afferent and efferent connections of the caudolateral neostriatum in the pigeon (Columba livia): a retro- and anterograde pathway tracing study. J Comp Neurol 407:228-260.

Kudo T, Konno K, Uchigashima M, Yanagawa Y, Sora I, Minami M, Watanabe M (2014): GABAergic neurons in the ventral tegmental area receive dual GABA/enkephalin-mediated inhibitory inputs from the bed nucleus of the stria terminalis. J Neurosci 39:1796-1809.

Kudo T, Uchigashima M, Miyazaki T, Konno K, Yamasaki M, Yanagawa Y, Minami M, Watanabe M (2012): Three types of neurochemical projection from the bed nucleus of the stria terminalis to the ventral tegmental area in adult mice. J Neurosci 32:18035-18046.

Kuenzel WJ, Medina L, Csillag A, Perkel DJ, Reiner A (2011): The avian subpallium: new insights into structural and functional subdivisions occupying the lateral subpallial wall and their embryological origins. Brain Res 1424: 67-101.

Legaz I (2006): Caracterización genética y origen de las neuronas de la región claustroamigdalina en ratón; doctoral thesis, University of Murcia, Murcia.

Li H, Penzo MA, Taniguchi H, Kopec CD, Huang ZJ, Li B (2013): Experience-dependent modification of a central amygdala fear circuit. Nat Neurosci 16:332-339.

López Avalos MD, Mancera JM, Pérez-Fígares JM, Fernández-Llebrez P (1993): Immunocytochemical localization of corticotropin-releasing factor in the brain of the turtle, Mauremys caspica. Anat Embryol (Berl) 188:163171

Marchant NJ, Densmore VS, Osborne PB (2007): Coexpression of prodynorphin and corticotrophin-releasing hormone in the rat central amygdala: evidence of two distinct endogenous opioid systems in the lateral division. J Comp Neurol 504:702-715.

Martínez-García F, Novejarque A, Lanuza E (2007): Evolution of the amygdala in vertebrates; in Kaas JH (ed): Evolution of Nervous Systems. A Comprehensive Reference, vol. 2. Oxford, Elsevier-Academic Press, pp 255334.

Martínez-García F, Novejarque A, Lanuza E (2008): Two interconnected functional systems in the amygdala of amniote vertebrates. Brain Res Bull 75:206-213.

Matsuda K, Morimoto N, Hashimoto K, Okada R, Mochida H, Uchiyama M, Kikuyama S (2010): Changes in the distribution of corticotropin-releasing factor (CRF)-like immunoreactivity in the larval bullfrog brain and the involvement of CRF in the cessation of food intake during metamorphosis. Gen Comp Endocrinol 168:280-286. DOI: 10.1016/j.ygcen.2010.01.004
McDonald AJ, Shammah-Lagnado SJ, Shi C, Davis $M$ (1999): Cortical afferents to the extended amygdala. Ann NY Acad Sci 877:309-338.

Medina L, Abellán A (2012): Subpallial structures in Watson C, Paxinos G, Puelles L (eds): The Mouse Nervous System. Amsterdam, Elsevier-Academic Press, pp 173-220.

Medina L, Abellán A, Vicario A, Desfilis E (2014): Evolutionary and developmental contributions for understanding the organization of the basal ganglia. Brain Behav Evol 83:112125.

Medina L, Bupesh M, Abellán A (2011): Contribution of genoarchitecture to understanding forebrain evolution and development, with particular emphasis on the amygdala. Brain Behav Evol 78:216-236.

Medina L, Legaz I, González G, De Castro F, Rubenstein JL, Puelles L (2004): Expression of Dbx1, Neurogenin 2, Semaphorin 5A, Cadherin 8, and Emx1 distinguish ventral and lateral pallial histogenetic divisions in the developing mouse claustroamygdaloid complex. J Comp Neurol 474:504-523.

Merchenthaler I, Lázár G, Maderdrut JL (1989): Distribution of proenkephalin-derived peptides in the brain of Rana esculenta. J Comp Neurol 281:23-39.

Moga MM, Gray TS (1985): Evidence for corticotropin-releasing factor, neurotensin, and somatostatin in the neural pathway from the central nucleus of the amygdala to the parabrachial nucleus. J Comp Neurol 241:275-284.

Moga MM, Saper CB, Gray TS (1989): Bed nucleus of the stria terminalis: cytoarchitecture, immunohistochemistry, and projection to the parabrachial nucleus in the rat. J Comp Neurol 283:315-332.

Molnar M, Casini G, Davis BM, Bagnoli P, Brecha NC (1994): Distribution of preproenkephalin mRNA in the chicken and pigeon telencephalon. J Comp Neurol 348:419-432.

Moreno N, Domínguez L, Morona R, González A (2012a): Subdivisions of the turtle Pseudemys scripta hypothalamus based on the expression of regulatory genes and neuronal markers. J Comp Neurol 520:453-478.

-Moreno N, Domínguez L, Rétaux S, González A (2008a): Islet1 as a marker of subdivisions and cell types in the developing forebrain of Xenopus. Neuroscience 154:1423-1439.

Moreno N, González A (2006): The common organization of the amygdaloid complex in tetrapods: new concepts based on developmental, hodological and neurochemical data in anuran amphibians. Prog Neurobiol 78:6190.

Moreno N, González A, Rétaux S (2009): Development and evolution of the subpallium. Semin Cell Dev Biol 20:735-743.

Moreno N, Morona R, López JM, Domínguez L, Joven A, Bandín S, González A (2012b): Characterization of the bed nucleus of the stria terminalis in the forebrain of anuran amphibians. J Comp Neurol 520:330-363. 
-Moreno N, Morona R, López JM, González A (2010): Subdivisions of the turtle Pseudemys scripta subpallium based on the expression of regulatory genes and neuronal markers. J Comp Neurol 518:4877-4902.

Moreno N, Rétaux S, González A (2008b): Spatiotemporal expression of Pax6 in Xenopus forebrain. Brain Res 1239:92-99.

- Nagarajan G, Tessaro BA, Kang SW, Kuenzel WJ (2014): Identification of arginine vasotocin (AVT) neurons activated by acute and chronic restraint stress in the avian septum and anterior diencephalon. Gen Comp Endocrino 202:59-68.

-Olivier C, Cobos I, Perez Villegas EM, Spassky N, Zalc B, Martinez S, Thomas JL (2001): Monofocal origin of telencephalic oligodendrocytes in the anterior entopeduncular area of the chick embryo. Development 128:1757-1769.

Osório J, Mueller T, Rétaux S, Vernier P, Wullimann MF (2010): Phylotypic expression of the bHLH genes Neurogenin2, Neurod, and Mash1 in the mouse embryonic forebrain. J Comp Neurol 518:851-871. DOI: 10.1002/ cne.22247.

Panguluri S, Saggu S, Lundy R (2009): Comparison of somatostatin and corticotrophin-releasing hormone immunoreactivity in forebrain neurons projecting to taste-responsive and non-responsive regions of the parabrachial nucleus in rat. Brain Res 1298:57-69.

-Paré D, Duvarci S (2012): Amygdala microcircuits mediating fear expression and extinction. Curr Opin Neurobiol 22:717-723.

-Paré D, Quirk GJ, LeDoux JE (2004): New vistas on amygdala networks in conditioned fear. J Neurophysiol 92:1-9.

Penzo MA, Robert V, Li B (2014): Fear conditioning potentiates synaptic transmission onto long-range projection neurons in the lateral subdivision of central amygdala. J Neurosci 34:2432-2437.

- Petrovich GD, Ross CA, Mody P, Holland PC, Gallagher M (2009): Central, but not basolateral, amygdala is critical for control of feeding by aversive learned cues. J Neurosci 29: 15205-15212.

-Phelps EA, LeDoux JE (2005): Contributions of the amygdala to emotion processing: from animal models to human behavior. Neuron 48:175-187.

- Poulin JF, Castonguay-Lebel Z, Laforest S, Drolet G (2008): Enkephalin co-expression with classic neurotransmitters in the amygdaloid complex of the rat. J Comp Neurol 506:943959.

Poulin JF, Chevalier B, Laforest S, Drolet G (2006): Enkephalinergic afferents of the centromedial amygdala in the rat. J Comp Neurol 496:859-876.

- Puelles L, Kuwana E, Puelles E, Bulfone A, Shimamura K, Keleher J, Smiga S, Rubenstein JL (2000): Pallial and subpallial derivatives in the embryonic chick and mouse telencephalon, traced by the expression of the genes Dlx-2, Emx-1, Nkx-2.1, Pax-6, and Tbr-1. J Comp Neurol 424:409-438
Puelles L, Martínez de la Torre M, Paxinos G, Watson C, Martinez S (2007): The Chick Brain in Stereotaxic Coordinates. An Atlas featuring Neuromeric Subdivisions and Mammalian Homologies. San Diego, Academic Press (Elsevier).

Real MA, Heredia R, Labrador MC, Dávila JC, Guirado S (2009): Expression of somatostatin and neuropeptide $\mathrm{Y}$ in the embryonic, postnatal, and adult mouse amygdalar complex. J Comp Neurol 513:335-348.

Real MA, Pineda D, Dávila JC, Guirado S (2008): Development and adult organization of the lateral part of the bed nucleus of the stria terminalis in the chicken. Brain Res Bull 75:410413.

Reiner A (1987): The distribution of proenkephalin-derived peptides in the central nervous system of turtles. J Comp Neurol 259:65-91.

Reiner A, Davis BM, Brecha NC, Karten HJ (1984): The distribution of enkephalinlike immunoreactivity in the telencephalon of the adult and developing domestic chicken. J Comp Neurol 228:245-262.

Reiner A, Karten HJ, Solina AR (1983): Substance P: localization within paleostriatal-tegmental pathways in the pigeon. Neuroscience 9:61-85.

Reiner A, Perkel DJ, Bruce LL, Butler AB, Csillag A, Kuenzel W, Medina L, Paxinos G, Shimizu T, Striedter G, Wild M, Ball GF, Durand S, Güntürkün O, Lee DW, Mello CV, Powers A, White SA, Hough G, Kubikova L, Smulders TV, Wada K, Dugas-Ford J, Husband S, Yamamoto K, Yu J, Siang C, Jarvis ED; Avian Brain Nomenclature Forum (2004): Revised nomenclature for avian telencephalon and some related brainstem nuclei. J Comp Neurol 473:377-414.

Richard S, Martínez-García F, Lanuza E, Davies DC (2004): Distribution of corticotropin-releasing factor-immunoreactive neurons in the central nervous system of the domestic chicken and Japanese quail. J Comp Neurol 469:559-580.

Saha S, Henderson Z, Batten TF (2002): Somatostatin immunoreactivity in axon terminals in rat nucleus tractus solitarii arising from central nucleus of amygdala: coexistence with GABA and postsynaptic expression of sst2A receptor. J Chem Neuroanat 24:1-13.

-Shimada S, Inagaki S, Kubota Y, Ogawa N, Shibasaki T, Takagi H (1989): Coexistence of peptides (corticotropin releasing factor/neurotensin and substance $\mathrm{P} /$ somatostatin) in the bed nucleus of the stria terminalis and central amygdaloid nucleus of the rat. Neuroscience 30:377-383.

Sokolowski K, Corbin JG (2012): Wired for behaviors: from development to function of in nate limbic system circuitry. Front Mol Neurosci 5:55.

Soria JM, Valdeolmillos M (2002): Receptor-activated calcium signals in tangentially migrating cortical cells. Cereb Cortex 12:831-839.
Spassky N, Olivier C, Cobos I, LeBras B, GoujetZalc C, Martínez S, Zalc B, Thomas JL (2001) The early steps of oligodendrogenesis: insights from the study of the plp lineage in the brain of chicks and rodents. Dev Neurosci 23 318-326.

Thor S, Ericsson J, Brannstrom T, Edlund T (1991): The homeodomain LIM protein lsl-1 is expressed in subsets of neurons and endocrine cells in the adult rat. Neuron 7:881-889.

Varela-Echavarría A, Pfaff SL, Guthrie S (1996): Differential expression of LIM homeobox genes among motor neuron subpopulations in the developing chick brain stem. Mol Cell Neurosci 8:242-257.

Vicario A, Abellán A, Desfilis E, Medina L (2014) Genetic identification of the central nucleus and other components of the central extended amygdala in chicken during development. Front Neuroanat 8:90.

Waclaw RR, Ehrman LA, Pierani A, Campbell K (2010): Developmental origin of the neuronal subtypes that comprise the amygdalar fear circuit in the mouse. J Neurosci 30:69446953.

Walker DL, Davis M (2008): Role of the extended amygdala in short-duration vs. sustained fear: a tribute to Dr. Lennart Heimer. Brain Struct Funct 213:29-42.

Walker DL, Miles LA, Davis M (2009): Selective participation of the bed nucleus of the stria terminalis and CRF in sustained anxiety-like versus phasic fear-like responses. Prog Neuropsychopharmacol Biol Psychiatry 33:12911308.

Wohlgemuth S, Adam I, Scharff C (2014): FoxP2 in songbirds. Curr Opin Neurobiol 28C:8693.

Wullimann MF, Rink E, Vernier P, Schlosser G (2005): Secondary neurogenesis in the brain of the African clawed frog, Xenopus laevis, as revealed by PCNA, Delta-1, Neurogenin-related-1, and NeuroD expression. J Comp Neurol 489:387-402.

Xu Q, Tam M, Anderson SA (2008): Fate mapping Nkx2.1-lineage cells in the mouse telencephalon. J Comp Neurol 506:16-29.

Yamamoto K, Sun Z, Wang HB, Reiner A (2005): Subpallial amygdala and nucleus taeniae in birds resemble extended amygdala and medial amygdala in mammals in their expression of markers of regional identity. Brain Res Bull 66:341-347.

Yao M, Westphal NJ, Denver RJ (2004): Distribution and acute stressor-induced activation of corticotrophin-releasing hormone neurones in the central nervous system of Xenopus laevis. J Neuroendocrinol 16:880-893.

Yun K, Garel S, Fischman S, Rubenstein JL (2003): Patterning of the lateral ganglionic eminence by the Gsh1 and Gsh2 homeobox genes regulates striatal and olfactory bulb histogenesis and the growth of axons through the basal ganglia. J Comp Neurol 461:151-165.
Islet 1 and Pax6 Cells of Chicken Central Extended Amygdala
Brain Behav Evol 2015;85:139-169

DOI: $10.1159 / 000381004$ 